Cornell Law Library

Scholarship@Cornell Law: A Digital Repository

Cornell Law Faculty Publications

Faculty Scholarship

2-24-2012

\title{
Rescuing the Invention from the Cult of the Claim
}

Oskar Liivak

Cornell LawSchool, ol10@cornell.edu

Follow this and additional works at: http://scholarship.law.cornell.edu/facpub

Part of the Intellectual Property Commons, and the Torts Commons

\section{Recommended Citation}

Liivak, Oskar, "Rescuing the Invention from the Cult of the Claim" (2012). Cornell Law Faculty Publications. Paper 598.

http://scholarship.law.cornell.edu/facpub/598

This Article is brought to you for free and open access by the Faculty Scholarship at Scholarship@Cornell Law: A Digital Repository. It has been accepted for inclusion in Cornell Law Faculty Publications by an authorized administrator of Scholarship@Cornell Law: A Digital Repository. For more information, please contact jmp8@cornell.edu. 


\title{
Rescuing the Invention from the Cult of the Claim
}

\author{
Oskar Liivak*
}

\section{INTRODUCTION}

Right now law professors around the country are introducing a fresh crop of students to the world of patent law. Early on we lecture about the importance of patent claims, pointing out that they are used to decide every important issue in patent law. ${ }^{1}$ Most importantly we tell our students that the claims define a patent's potent exclusive rights. "Claims are the most important part of the modern patent document." As stated by Judge Giles Rich, "[T] he name of the game is the claim."

Every once in a while an observant, bright-eyed student raises her hand and questions this claim-centric view. She begins by noting that patent law has been understood as "entirely statutory" from be-

- Associate Professor of Law, Cornell University Law School. This Article has benefitted from presentations at the 2010 Intellectual Property Scholars Conference held at the UC Berkeley School of Law. I especially thank Dan Burk, Kevin Collins, Christopher Cotropia, James Dabney, Rebecca Eisenberg, Robin Feldman, Paul Heald, Tim Holbrook, Mark Lemley, and Bradley Wendel for helpful comments and discussion. I also want to thank my student James Nault for invaluable help. An earlier draft benefitted from presentations at the 3rd Annual Junior Scholars in IP Workshop held at Michigan State University College of Law and the 2009 Intellectual Property Scholars Conference.

${ }^{1}$ Mark Lemley, The Changing Meaning of Patent Claim Terms, $104 \mathrm{MiCH}$. L. REv. 105,105 (2005) ("The claims of a patent are central to virtually every aspect of patent law. The claims define the scope of the invention, and their meaning therefore determines both whether a defendant's product infringes a patent and whether the patent is valid.").

${ }^{2}$ John F. Duffy, On Improving the Legal Process of Claim Interpretation: Administrative Alternatives, 2 WASH. U.J.L. \& POL'Y 109, 109 (2000).

${ }^{3}$ Giles S. Rich, Extent of Protection and Interpretation of Claims-American Perspectives, 21 INT'L REV. INDUS. PROP. \& COPYRIGHT L. 497, 499 (1990).

${ }^{4}$ Howard T. Markey, Why Not the Statute?, 65 J. PAT. OFF. SOC'Y 331, 331 (1983). Of course Judge Markey noted that there is "some judicial maneuvering within the interstices of the statute." Id. But he emphasized that

[o]ur concern here is with plain, simple disregard of the statuteevidenced in the promulgation of some words and phrases that muddy the decisional waters and other words and phrases that render the law as written by congress a nullity. In sum, when it comes to patent cases, 
fore the United States was even founded. ${ }^{5}$ She then points to the statute and its novelty requirement. It forbids a patent if "the invention was known" before not if the claimed subject matter was known before. $^{6}$ And similarly, for the important disclosure requirements, the patent applicant must provide a "written description of the invention" and must "enable [others] to make and use [the invention]." Most importantly, she then points out that the statute grants exclusive rights in the "patented invention," not the claimed subject matter. She innocently asks how the claims can be so central in patent law when the statute refers instead to the invention. Why is the invention not the central concept in patent law?

The eyes of the class return to the lectern. Our pulse quickens (hopefully not visibly) and we recall our rehearsed script. ${ }^{9}$ We compliment the student on her close statutory reading but we quickly add (hopefully not condescendingly) that the modern patent system is now a peripheral claiming system and within that system the invention is defined by the claimed subject matter. In other words, though the statute refers to the invention, those statutory references should be read as references to the claims. As summarized nicely by Jeffrey Lefstin, "In modern parlance, 'the claim,' 'the invention,' and the 'the patent' are essentially synonymous." There is no discrepancy because focusing on the claims is focusing on the invention. The invention is nothing more than a short-hand reference for the claimed subject matter. To back our position we quote the Supreme Court as stating that " $[u]$ nder the statute it is the claims of the patent which

\footnotetext{
the statute is the law-and court opinions containing language and concepts contrary to the statute are unlawful.

Id.

See Donaldson v. Beckett (1774) 1 Eng. Rep. 837; Wheaton v. Peters, 33 U.S. (8 Pet.) 591 (1834).

63 U.S.C. $\S 102$ (2006). And recently Congress passed the first major overhaul of the patent laws since 1952. The new $\$ 102$ changed slightly shifting the focus from the "invention" to the "claimed invention." See Leahy-Smith America Invents Act, Pub. L. No. 112-29; 125 Stat. 284 (2011) (to be codified at 35 U.S.C.). That change does not impact the analysis or arguments in this article. The claimed invention is just a subset of the invention. Interestingly, note that 35 U.S.C. $\$ 103$ does not place the invention at the center of its test. It looks instead to the obviousness of the difference between "the subject matter sought to be patented and the prior art." Id. $\S 103(\mathrm{a})$.

Id. $\$ 112$.

8 Id. $\S 271$.

${ }^{2}$ I thank James Dabney for describing this as a script that the patent bar is taught to follow.

${ }_{10}$ Jeffrey A. Lefstin, The Formal Structure of Patent Law and the Limits of Enablement, 23 BERKELEY TECH. L.J. 1141, 1145 (2008).
} 
define the invention." ${ }^{11}$ And we point to the Court of Appeals for the Federal Circuit, which has further elaborated this "bedrock principle of patent law that the claims of a patent define the invention to which the patentee is entitled the right to exclude." ${ }^{12}$ From the Supreme Court on down, it is understood that the claims are legal devices to delineate "the patentee's right to exclude," ${ }^{, 13}$ and the invention is just a short hand reference for those legal boundaries. We explain that the statutory references to "the invention" can be viewed as a redundant "anachron [ism]" that in our modern system we could just as well replace with the claims. ${ }^{14}$ In fact we should not think of the claims as "[w] hat the inventors invented," but rather as just directly delineating "the right to exclude." 15

Having forcefully delivered the orthodox line and to underscore its correctness, we quickly return to the lecture and the rest of patent law. A clear unspoken message has been sent: there is nothing interesting to explore here. To talk about "the invention" instead of the claims is an "old-fashioned" way to think about patent law. ${ }^{16}$ When the spark of that student's curiosity fades and when this orthodoxy is accepted, the student unknowingly and unfortunately becomes the latest member indoctrinated into modern patent law's cult of the claim.

At first as the student continues her study of patent law, a fairly coherent, formal framework emerges. ${ }^{17}$ The claim-centric system seems to fit with patent law's ongoing drive towards "precision" and

"Altoona Publix Theatres, Inc. v. Am. Tri-Ergon Corp., 294 U.S. 477, 487 (1935); see also Aro Mfg., Co. v. Convertible Top Replacement Co., 365 U.S. 336, 339 (1961); McClain v. Ortmayer, 141 U.S. 419, 424 (1891).

${ }_{12}$ Innova/Pure Water, Inc. v. Safari Water Filtration Sys., Inc., 381 F.3d 1111, 1115 (Fed. Cir. 2004); see also Chris Cotropia, What is the Invention? (Aug. 29, 2011) (unpublished manuscript) (on file with author), available at http://papers.ssrn.com/so13/papers.cfm?abstract_id=1918841.

${ }_{13}$ Giles S. Rich, Foreword to F. SCOTt Kieff et al., Principles of Patent Law, at iii, v-vi (4th ed. 2008).

${ }_{14} I d$. at $\mathrm{v}$.

${ }^{15}$ Id. at v-vi. To foreshadow the criticism of this framework that follows below, note that this vision for the patent system forces a very strained interpretation of the invention. The plain meaning of the invention is the thing or things invented. Yet in the modern understanding of patent law the invention is now just a term of art decoupled from what was actually invented.

${ }_{16}$ Transcript of Oral Argument at 52-53, KSR Int'l Co. v. Teleflex, Inc., 550 U.S. 398 (2007) (No. 04-1350).

${ }^{17}$ See generally Lefstin, supra note 10 (describing the formal structure of the modern claim-centric patent system). 
"accuracy." ${ }^{18}$ The 1952 Patent Act itself was written expressly in hopes of producing "a strong and reliable patent system."19 And even the Court of Appeals for the Federal Circuit, the court that hears all patent appeals, was itself created with the purpose of reducing "confusion and uncertainty" in patent law.

Yet on closer inspection, long after that basic bedrock principle of the cult has deeply cemented itself in our understanding, serious cracks and blemishes appear. Modern patent law has been incapable of articulating a coherent view for two critically important doctrinal areas: claim interpretation and the disclosure requirements. Claim interpretation has been described as the "festering sore of uncertainty in Federal Circuit patent jurisprudence," quirements are considered "a welter of confused and confusing precedent that not only defies restatement, but also renders analysis and synthesis distinctly unmanageable.,"22

So what is happening? This Article argues that these cracks and blemishes result from building the patent system on a faulty foundation. It argues that the cult, its vision for patent law, and its "bedrock principle" are based on an incorrect interpretation of the invention. Yet, a substantive discussion of the invention as a statutory concept is nowhere to be found in modern patent doctrine or scholarship.

${ }_{18}$ Merrill v. Yeomans, 94 U.S. 568, 573 (1876); see also Karl B. Lutz, Evolution of the Claims of U.S. Patents, 20 J. PAT. OFF. SOC'Y 457, 464 (1938).

${ }^{19}$ Donald W. Banner, Foreword to Nonobviousness-The Ultimate Condition of Patentability, at v, v (John F. Witherspoon ed., 1980).

${ }^{20}$ R. Polk Wagner \& Lee Petherbridge, Is the Federal Circuit Succeeding? An Empirical Assessment of Judicial Performance, 152 U. PA. L. REv. 1105, 1108 (2003). "Indeed, as a response to widespread dissatisfaction due to confusion and uncertainty under the decentralized administration of the patent law, the Federal Circuit was created to play this very role." Id.

${ }_{21}$ Harold C. Wegner, Arlington Indus. v. Bridgeport Fittings: The 20 Year Claim Construction Debate, IP FRONTLINE (Jan. 24, 2011), http://www.ipfrontline.com/ depts/article aspx?id=24829\&deptid=7.

${ }^{22}$ Robert L. Harmon, Must a Patent Describe an Accused Infringement?, 85 J. PAT. \& TRADEMARK OFF. SOC'Y 153, 154 (2003).

${ }^{23}$ The one recent exception is Cotropia, supra note 12 . Earlier, the only article was written by Paul Janicke, but to a large extent that article essentially detailed an interpretation of the invention similar to the cult. See Paul Janicke, The Varied Meanings of "Invention" in Patent Practice: Different Meanings in Different Situations, in 4 Patent Law Perspectives, at App. 1 (Donald R. Dunner et al., eds., 1970). Recent work by Tun-Jen Chiang uses the term invention, but he ultimately concludes that there can be no right definition of the invention, and therefore, it should just be a vehicle for a realist judge to impose his or her policy choices. Tun-Jen Chiang, The Levels of Abstraction Problem in Patent Law, 105 Nw. L. REv. (forthcoming 2012) (on file with author). This Article does not agree with that usage, nor is Chiang's usage really an attempt to understand the statutory usage of the invention. 
Consult any modern treatise or casebook and you will not find an in depth discussion. ${ }^{24}$ Modern patent law just assumes that the cult's view is correct and that the topic needs no further thought. It is time to rekindle the spark of that student's question, time to question the cult of the claim, and time to rethink the invention. This Article argues that the cult's vision of the invention and its concomitant framework for patent law are inconsistent not only with the statute but they lead us to a patent system that grants exclusive rights that exceed patent law's constitutionally mandated limits.

This Article argues that the invention is not simply a shorthand reference for the claimed subject matter as the cult believes. Claims are not written to directly delineate a patent's exclusionary rights. Correctly interpreted, the invention is a substantive, technical concept. The invention is the inventor's own solution to some technical problem for which the inventor seeks a patent. In other words, the invention is what the inventor actually invented and disclosed in the patent application. In patent jargon, the invention is the set of embodiments conceived and disclosed by the inventor in enough detail that they can be reduced to practice. Claims still play an important part in this patent system, but they function as tools that aid in the process of determining the invention. Claims are written to help delineate the contours of the technical invention described in the patent. Those claims then indirectly lead to exclusive rights because they help courts determine what constitutes the patentable invention. This Article will lay out the evidence in support of this substantive interpretation of the invention and the benefits that accrue from employing it to structure our patent system.

This Article argues that there are a number of reasons for first exploring and then adopting this substantive, technical vision of the invention. First, when we explore the invention, it becomes clear that the cult's trivial vision of the invention cannot be correct. The cult requires a strained reading of the statute and it leads to patents whose scope exceeds constitutional limitations. In contrast, the substantive vision is consistent with the statute, and it respects the limits imposed on patent law by the Constitution. Second, this substantive vision of the invention provides a comprehensive way to interpret the disclosure requirements that can resolve the ongoing debates preventing consensus. With the substantive view, the disclosure requirements simply ask the inventor to document his invention. Last-

${ }_{24}$ See, e.g., JANice Mueller, PATENT LAW 67 (3d ed. 2009) (giving the standard definition of the invention under the cult but providing no further support for that definition). 
ly, the substantive vision recasts the purpose of the claims, which resolves the debates over claim interpretation. For the cult, claims are direct delineations of a patent's right to exclude and they are interpreted accordingly. The specification only bears a tangential relationship to claim interpretation. In contrast, the substantive view views the claims as written to highlight the invention disclosed in the specification. In other words, claims are written to satisfy the statutory requirement to "particularly point[] out and distinctly claim[] the subject matter which the applicant regards as his invention." ${ }^{25}$ And under the substantive view, claims should be interpreted accordingly. The substantive vision gives claims critically important contextual meaning by tying the purpose of the claims to the overall purpose of the specification. The claims are not abstract legal boundaries, but rather, they "particularly point[] out and distinctly claim[]" the actual substantive invention described by the specification. ${ }^{26}$ This context should add uniformity and stability to the process of claim interpretation.

The rest of this Article examines these issues in more detail. Following this introduction, Part II outlines the cult of the claim and its framework for patent law. Then Part III introduces the substantive view of the invention and the evidence supporting it. This Part shows how the originality requirement violated by the cult is inherently respected by this substantive vision of the invention. Part IV highlights how current patent case law is best understood as a mix of the trivial and substantive visions of the invention. It emphasizes how the substantive vision of the invention can recast the current debates over claim interpretation and the disclosure requirements. It also shows how substantive invention changes the role of claims and how that change should improve stability and precision in claim interpretation. Part $V$ explores the history of the invention and explains how this central term was emptied of substantive content. Part VI outlines further areas of study regarding substantive invention and patent law.

\section{THE CULT OF THE Claim AND ITS VISION FOR PATENT LAW}

This Part describes the trivial view of the invention that is at the heart of the cult of the claim. In this view, the invention is just a shorthand reference for the claimed subject matter. This Part describes the statutory and precedential basis for this view, and it then

${ }^{25} 35$ U.S.C. $§ 112$ I 2 (2006).

${ }^{26}$ Id. 
describes the overall patent system that flows from rigorously applying this view of the invention to the patent statute.

\section{A. The Cult and Its Bedrock Principle}

In the cult, the statutory starting point for understanding patent law is 35 U.S.C. $\S 112$ I 2. It requires a patent applicant to conclude the specification, the main portion of the patent application, "with one or more claims particularly pointing out and distinctly claiming the subject matter which the applicant regards as his invention.",27 Referring to this provision, the Supreme Court has stated that " $[u]$ nder the statute, it is the claims of the patent which define the invention." ${ }^{28}$ Other Supreme Court cases similarly emphasize that "the claims made in the patent are the sole measure of the grant.", And that " $[t]$ he claim is the measure of [the patentee's] right to relief." $^{30}$ From these statements, a long line of Federal Circuit cases state the "bedrock principle' of patent law that 'the claims of a patent define the invention to which the patentee is entitled the right to exclude." ${ }^{31}$ Because the claims define the invention, the invention itself has no substantive existence other than as a shorthand for the subject matter that a patentee can claim.

Judge Giles Rich, recounting the drafting of the 1952 Patent Act, stated that "[o]ne apparent thought... was to stop talking about whether a thing is or is not an 'invention,' to take anything presented as an invention, and then to determine its patentability according to a standard which Congress was to declare [in the 1952 Act]., ${ }^{32}$ In short, "there is always an invention-and the issue is its patentability.", In essence, your invention is whatever you claim it to be."

${ }^{27} I d$.

${ }^{28}$ Altoona Publix Theatres, Inc. v. Am. Tri-Ergon Corp., 294 U.S. 477, 487 (1935).

${ }^{29}$ Aro Mfg., Co. v. Convertible Top Replacement Co., 365 U.S. 336, 339 (1961).

30 McClain v. Ortmayer, 141 U.S. 419, 424 (1891).

31 Phillips v. AWH Corp., 415 F.3d 1303, 1312 (Fed. Cir. 2005) (quoting Innova/Pure Water, Inc. v. Safari Water Filtration Sys., Inc., 381 F.3d 1111, 1115 (Fed. Cir. 2004)); see also Cotropia, supra note 12.

${ }^{32}$ Giles S. Rich, The Vague Concept of "Invention" as Replaced by Section 103 of the 1952 Patent Act, in NoNOBVIOUSNESS, supra note 19, at 1:401, 1:407.

${ }^{99}$ Giles S. Rich, Escaping the Tyranny of Words-Is Evolution of Legal Thinking Impossible, in NoNOBVIOUSNESS, supra note 19, at 3:301, 3:306.

3. See Janice M. Mueller, The Evolving Application of the Written Description Requirement to Biotechnological Inventions, 13 BERKELEY TECH. L.J. 615, 638 (1998) ("By claiming human insulin-encoding cDNA at the time they filed the application for the ' 525 patent, UC conveyed to the art that the human cDNA was something it had invented. This is all that written description requires."). 
In this view, claims are "the sole measure of the invention," they form the "cornerstone" of the modern patent system. ${ }^{36}$ In this system, as argued by Judge Giles Rich, "the sole function of [a] patent claim[]" is "to determine the scope of the right to exclude." The claims in a patent application are the subject matter over which the applicant is requesting exclusive rights in exchange for their disclosure. The invention, the claims, and the patent's exclusive rights are conceptually seen as synonymous.

\section{B. General Framework for Patent Law Under the Cult}

Because the cult defines the invention to be whatever is claimed, the cult's patent system simply takes every statutory appearance of the invention and replaces it with the claims. ${ }^{39}$ The result is that every substantive aspect of patent law is controlled by the claims. As described by one of the leading modern treatises, "the claim defines the invention for purposes of both patentability and infringement."

The claims in a patent application are conceptual fences that mark off the subject matter that the applicant is seeking exclusivity over in exchange for their disclosure. The sole purpose of patent examination is to determine if the applicant in fact deserves that amount of exclusivity. The patent requirements, 35 U.S.C. $\$ \S 101$, $102,103 \& 112$, are all seen as ensuring that the exclusive rights are commensurate with the information disclosed. In checking if exclusivity is commensurable with the disclosure, the first step is construing the claim language. By construing the claim language, we are determining the exact subject matter over which the patentee is requesting exclusive rights. The various tests set by the statute are then

${ }^{35}$ Lefstin, supra note 10, at 1145; see also id. at $1145 \mathrm{n} .15$ (noting the modern "synonymy of invention and claim").

${ }^{36}$ Id. at 1145.

${ }^{37}$ MUELLER, supra note 24, at 67 (quoting Judge Giles S. Rich).

${ }^{38}$ Id. Although he has not used these terms explicitly, Timothy Holbrook has advocated for a slightly different conceptual definition of the invention. See Timothy Holbrook, Possession in Patent Law, 59 SMU L. Rev. 125 (2006). Rather than being the claims themselves, the invention is the enabled subject matter. Id. at 147. In other words, "the invention" that corresponds to a patent specification is all the subject matter that is enabled by that specification. As to its substantive reach, his possession-based patent system differs little from the modern system, and Holbrook, like the pure claim-centric system, finds no need for a disclosure requirement in addition to enablement. Id. at 133. In short, his system does not change the substantive reach of the claim-centric system, but it does try to provide a more coherent framework for a patent system with that substantive reach. See id. at 125.

${ }_{39}$ See DONALD CHISUM, CHISUM ON PATENTS $§ 8.01$ (2008).

4 Id. $\S 7.03$. 
compared against that requested claim scope, and the patent system determines if the patentee deserves that claim scope. The invention is the exclusivity that is sought. If the patentee jumps through all the statutory hoops, then that requested claim scope is allowed and it becomes the "patented invention," which defines the exclusivity that can be enforced in court. Chart 1 gives a summary of the process of claim validity as understood by the cult, and Figure 1 gives a graphical representation of claim scope as understood by the cult.

\section{Chart 1: Valid Claims Under Trivial Invention}

1. Interpret/construe claims:

- Purpose of claims: Claims directly demarcate the boundary of exclusion.

- Claim interpretation/construction: Determine what boundary the drafter intended to demarcate.

- The plain meaning prevails unless idiosyncratic definitions in the specification indicate intent to demarcate with other than the plain meaning.

- Presume that the drafter intends to claim as much as the patent system allows (i.e., the patent's contribution).

2. Determine if the claimed subject matter is commensurate with the patent's contribution:

- Patent Contribution = Enabled Subject Matter - Obvious Subject Matter

- Enabled subject matter includes everything that a person of skill, after reading the specification, could make and use (if asked to) without undue experimentation. Enabled subject matter extends well beyond embodiments invented and disclosed by the inventor.

- The disclosed embodiments form the starting point for (not limit of) the enabled subject matter.

- If a claim is commensurate with the patent's contribution then it is valid. 


\section{Figure 1: Claim Scope Under Trivial Invention}

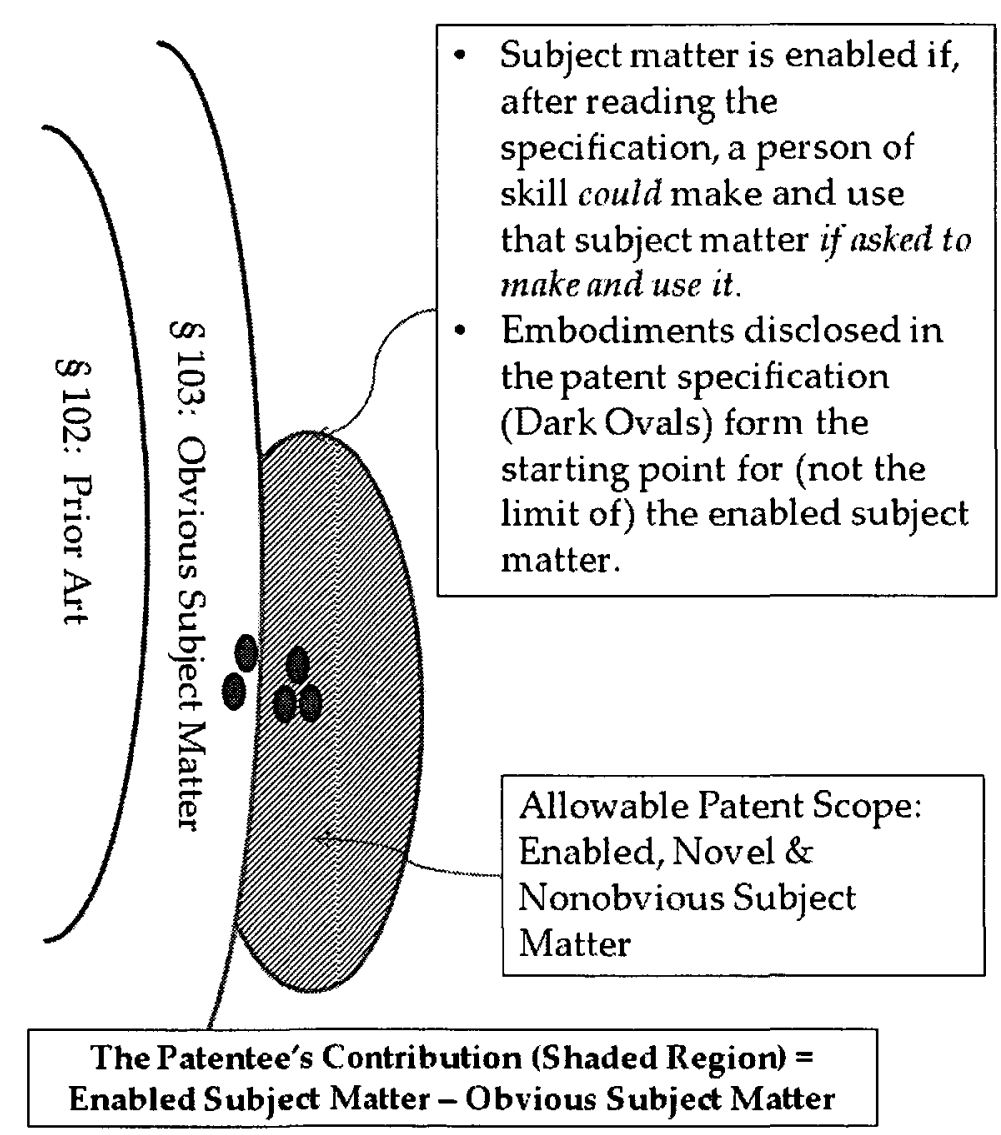

\section{The Cult and Claim Construction}

The cult's view of the invention has important implications for claim construction. For the cult, the sole purpose of a claim is to communicate a conceptual boundary to people skilled in the art. The claims in a patent application are conceptual fences that mark off subject matter that the applicants think they deserve in exchange for their disclosure. They are intended to tell potential infringers, absent a license from the patent owner, what subject matter they should avoid. 
The words of the claim are then interpreted according to this purpose. The claim terms "bear a 'heavy presumption' that they mean what they say and have the ordinary meaning that would be attributed to those words by persons skilled in the relevant art." portantly, in this view there is no special relationship between claim construction and the specification. The only time the specification is relevant is when "the patentee, acting as his or her own lexicographer, has clearly set forth an explicit definition of the term different from its ordinary meaning or ... if the inventor has disavowed or disclaimed scope of coverage.."

Importantly, the cult presumes that claim drafters will attempt to claim all that they can. As will be shown below, the cult's views on enablement allow quite broad claims for fairly meager disclosures and this in turn means that, according to the cult, claim construction should also avoid canons of construction that would prevent patentees from accessing such broad claims. As suggested below, in the cult's view, patent claims can regularly extend beyond the embodiments explicitly disclosed and examined in the specification. Claim language should not be interpreted to be limited to those embodiments. For this reason, the cult is very wary of the use of the specification in claim interpretation because it may tempt judges to "read[] limitations from the specification into the claim."

\section{The Cult, Disclosure, and Ultimate Claim Scope}

In the cult's vision for patent law, the disclosure requirements play a critical role; they ensure that the claims are roughly commensurate with the disclosure. The disclosure requirements ask "the ... fundamental question: To what scope of protection is this applicant's particular contribution to the art entitled?"

The disclosure requirements found in 35 U.S.C. $\S 112$ II $1^{45}$ require a specification that

contain[s] a written description of the invention, and of the manner and process of making and using it, in such full, clear, concise, and exact terms as to enable any person skilled in the art 2002).

${ }^{41}$ Tex. Digital Sys., Inc. v. Telegenix, Inc., 308 F.3d 1193, 1201-02 (Fed. Cir.

${ }^{42}$ Phillips v. AWH Corp., 415 F.3d 1303, 1319 (Fed. Cir. 2005) (en banc).

${ }^{43}$ Id. at 1323 .

44 In re Hogan, 559 F.2d 595, 606 (C.C.P.A. 1977).

${ }^{45}$ For ease of discussion, 35 U.S.C. $\$ 112$ I 1 will refer only to the non-best mode portion of the statute. 
to which it pertains, or with which it is most nearly connected, to make and use the same.

Two sub-requirements are generally found in this language: the written description requirement and enablement. The written description requirement is generally rooted in the requirement that the specification shall contain "a written description of the invention," while the enablement requirement is rooted in the language mandating "such full, clear, concise, and exact terms as to enable any person skilled in the art to which it pertains, or with which it is most nearly connected, to make and use [the invention]."

For the cult, the standard procedure is to replace references to the invention with the claims. And indeed this procedure is followed even for the disclosure requirements. "The invention is, for purposes of the 'written description' inquiry, whatever is now claimed." ${ }^{48}$ Similarly, "[t]he 'invention' that must be enabled is that defined by the particular claim or claims of the patent or patent application." that definition and applying it to the first paragraph of 35 U.S.C. $\S$ 112 leads to a disclosure requirement that reads:

The specification shall contain a written description of the [claimed subject matter], and of the manner and process of making and using [the claimed subject matter], in such full, clear, concise, and exact terms as to enable any person skilled in the art to which it pertains, or with which it is most nearly connected, to make and use the [claimed subject matter] ... . ${ }^{50}$

Interpreting this language in light of a trivial vision of the invention produces immediate implications. First, the statute asks that the patentee file "a written description of the [claimed subject matter]." Many claims are filed with the initial application. These are called original claims. Under the trivial theory of invention, these originally filed claims easily satisfy this first requirement because they are by definition written.

This is not true, however, of later filed claims. Claims can be added or modified during patent prosecution and, for those claims to be valid, the patentee must show that the original specification provided "a written description of the [claimed subject matter]."52 When

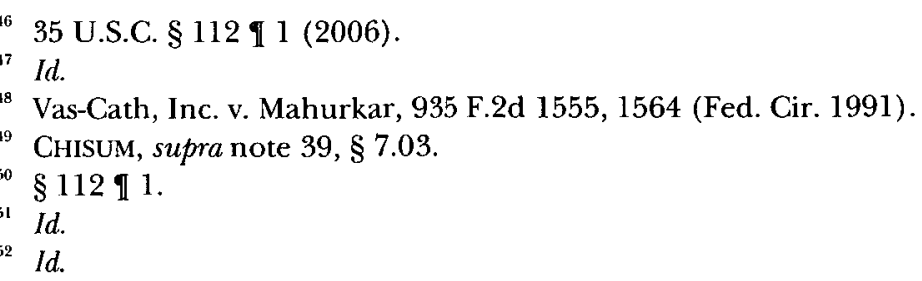


the specification is viewed this way, a patentee can only add a claim later if his initial specification indicates some intent to claim that later-added subject matter. In other words, under the trivial vision of the invention, the written description requirement only serves a public notice function and only applies to later filed claims. Indeed, this relatively minor notice and support-policing function for non-original claims has been urged by commentators and some Federal Circuit judges as the only function of the written description requirement. ${ }^{53}$

Second, in contrast to the relatively minor role for written description, the trivial vision of the invention assigns a very important role to enablement. ${ }^{54}$ That requirement is founded on the statutory language that the specification must contain "such full, clear, concise, and exact terms as to enable any person skilled in the art ... to make and use the [claimed subject matter]., ${ }^{55}$ Enablement is generally seen as "uncontroversial, ${ }^{, 56}$ and the more important of the two ${ }^{57}$ requirements as it ensures that the grant of exclusive rights is "commensurate" with the "contribution" or "teaching" of a patent's disclosure. It is the primary regulator that "embodies the quid pro quo of the patent system that an inventor's exclusive rights be commensurate with the benefits conferred on society by his disclosure. ${ }^{, 58}$

In particular, the cult's vision for patent law enablement allows quite broad claim scope. An applicant that "enable[s] any embodiment [within the scope of a claim] satisfies the enablement requirement regardless of the breadth of the claims." ${ }^{, 59}$ This was described by Robin Feldman as "the one embodiment doctrine." ${ }^{, 60}$ For example, in Gemstar-TV Guide International, Inc. v. ITC, the Federal Circuit stated that " $[t]$ his court has expressly rejected the contention that if a pa-

${ }^{53}$ See Enzo Biochem, Inc. v. Gen-Probe, Inc., 323 F.3d 956, 982 (Fed. Cir. 2002) (Rader, J., dissenting); Mueller, supra note 34, at 618-23.

${ }^{54}$ See Enzo Biochem, Inc., 323 F.3d at 982 (Rader, J., dissenting).

5535 U.S.C. $\$ 112$ I 1 (2006).

${ }^{56}$ Lefstin, supra note 10, at 1153.

$57 \quad I d$

${ }^{58} \quad$ Id. at 1182.

${ }_{59}$ Bernard Chao, Rethinking Enablement in the Predictable Arts: Fully Scoping the New Rule, 2009 Stan. Tech. L. Rev. 3, I 50 (2009); see also Robert Merges \& Richard R. Nelson, On the Complex Economics of Patent Scope, 90 Colum. L. Rev. 839, 845 (1990) ("This [enablement] requirement can at times be applied rather loosely: a specification that describes only one working example of an invention but that supplies less guidance on the subject matter at the fringes of a patent's claims is often sufficient.").

60 Robin Feldman, The Inventor's Contribution, 2005 UCL.A.J.L. \& TECH. 6, 24. 
tent describes only a single embodiment, the claims of the patent must be construed as being limited to that embodiment."

In this view, a claim is valid if the specification "enable[s] any person skilled in the art... to make and use the [claimed subject matter]." ${ }^{62}$ The Federal Circuit has further articulated that "[a]11 questions of enablement are evaluated against the claimed subject matter [and] [ $t$ ] he focus of the examination inquiry is whether the substantial scope of the claim is enabled." ${ }^{, 63}$ For example, in the case of In re DiLeone, the Court of Customs and Patent Appeals explored a hypothetical patent specification that "discusses only compound A and contains no broadening language of any kind. This might very well enable one skilled in the art to make and use compounds $\mathrm{B}$ and C." ${ }^{64}$ In other words, if asked to make and use B and C, a person of skill could do so based on the teaching of making and using A alone, and thus that patent would be deemed to have enabled A, B, and C. But nothing suggests that the inventor had conceived anything beyond A.

This formulation of the enablement inquiry is a leading question. The test has been applied by looking at the embodiments covered by a claim and asking a person of skill in the art if she could make and use those embodiments if asked to. The enablement test itself supplies critical information. It tells the person of skill what we want her to make and use, and because of that, the enablement inquiry, as interpreted by the cult, allows claims to cover subject matter not conceived by the inventor.

${ }^{61} 383$ F.3d 1352, 1366 (Fed. Cir. 2004) (quoting Liebel-Flarsheim Co. v. Medrad, Inc., 358 F.3d 898, 906 (Fed. Cir. 2004)) (internal quotation marks omitted); see also Phillips v. AWH Corp., 415 F.3d 1303, 1323 (Fed. Cir. 2005) (en banc); Gemstar-TV Guide, 383 F.3d at 1366 ("Our precedent has emphasized that the disclosure in the written description of a single embodiment does not limit the claimed invention to the features described in the disclosed embodiment."). The Liebel-Flarsheim court also noted:

Even when the specification describes only a single embodiment, the claims of the patent will not be read restrictively unless the patentee has demonstrated a clear intention to limit the claim scope using "words or expressions of manifest exclusion or restriction."

Liebel-Flarsheim, 358 F.3d at 906 (quoting Teleflex, Inc. v. Ficosa N. Am. Corp., 299 F.3d 1313, 1327 (Fed. Cir. 2002)).

62 35 U.S.C. § 112 I 1 (2006).

${ }^{63}$ AK Steel Corp. v. Sollac, 344 F.3d 1234, 1241 (Fed. Cir. 2003) (quoting In re Wright, 999 F.2d 1557, 1561 (Fed. Cir. 1993)).

${ }_{64} 436$ F.2d 1404, 1405 n.l (C.C.P.A. 1971); see also Mark D. Janis, On Courts Herding Cats: Contending with the "Written Description" Requirement (and Other Unruly Patent Disclosure Doctrines), 2 WASH. U.J.L. \& POL'Y 55 (2000). 
Importantly, the embodiments disclosed in the specification are not the limit of the allowable subject matter, rather, they form the starting point from which the claim scope negotiation begins. The claims can extend to any subject matter that "one skilled in the art, after reading the[] disclosures, could practice... without undue experimentation."

The result is that " $[c]$ laims are frequently a far cry from what the inventor invented." ${ }^{, 66}$ For example, a recent paper describes the relatively uncontroverted conventional view that

despite the black-letter rule that an inventor can lawfully claim only what he has invented and described, courts and the Patent Office typically allow patent claims that are of much broader scope than what is actually disclosed in a patent application. Specifically, a patent will usually disclose just one or a few embodiments of the invention in the patent's specification, but will often claim thousands of different embodiments in a claim.

Similarly, others describe that "the patent system allows an inventor to reach to far more than what the inventor has actually done." ${ }^{.68}$ And Janice Mueller has argued that the patent system generally "has always provided more in terms of patent scope than merely those embodiments expressly disclosed by the inventor in her application., ${ }^{, 69}$ As will be shown in Part III, this broad allowable claim scope forms the central criticism of the cult's view as it allows claims that exceed the limits set by the statute and the Constitution.

$$
* * * *
$$

In conclusion, the cult, by applying its bedrock principle to the patent statute, has developed a particular vision of both the disclosure requirements and claim interpretation. The disclosure requirements are characterized by a heavy emphasis on enablement and no role for written description in the context of original claims. Patentees are allowed to claim any and all subject matter that could be made by a person of skill (without undue experimentation) ${ }^{70}$ after reading the specification if she was asked to. Furthermore, as claims represent a patent's exclusionary boundaries, claim construction aims to determine what boundary of exclusion the applicant sought to

${ }^{65}$ Chiron Corp. v. Genentech, Inc., 363 F.3d 1247, 1253 (Fed. Cir. 2004).

${ }^{66}$ MUELLER, supra note 24, at 67 (quoting Judge Giles S. Rich).

${ }^{67}$ Ted Sichelman, Commercializing Patents, 62 STAN. L. REV. 341, 356 (2010) (internal quotations and citations omitted).

${ }_{68}^{68}$ Feldman, supra note 60, at 24.

${ }^{69}$ Mueller, supra note 34 , at 651.

${ }^{70}$ See In re Wands, 858 F.2d 731, 736-37 (Fed. Cir. 1988). 
demarcate. This puts a heavy emphasis on the plain meaning of the claim terms. And as the cult would allow quite broad claims that extend well beyond the specification, the cult aims to avoid importing limitations from the specification. The next Part will show that this vision of the patent system is wrong and it leads to numerous problems in patent law, especially for the disclosure requirements, the ultimate scope of claims, and for claim interpretation.

\section{SUBSTANTIVE INVENTION AND ITS VISION FOR PATENT LAW}

This Part argues that the cult's view of the invention is wrong. In the correct view, the subject matter invented by the inventor exists before a patent is ever filed and before any claims have been written. Inventors provide utility because they solve problems. The thing invented by inventors is their solution to some problem; it is the inventor's means to some useful end. It is the solution that has been conceived by the inventor in enough detail so that it is capable of being reduced to practice. With this substantive view of the invention, a different patent system emerges from the patent statute. ${ }^{71}$ Not only is this the correct interpretation but it also leads to a patent system with improved accuracy and precision.

The substantive view of the invention leads to a patent system in which validity is divided into two sections. The ultimate goal is to determine if the patent application contains a "patentable invention.",72 This entails two distinct determinations. First, what was invented? And then, is that invention patentable? The first determination is made by a combination of 35 U.S.C. $\S 101$ and the disclosure requirements of 35 U.S.C. $\$ 112$ II 1-2. Section 101 is a threshold inquiry asking whether anything has been invented, and if so, $\$ 112$ de-

"Tun-Jen Chiang has described something similar and called it the "unitary invention principle." Chiang, supra note 23, at 8 . And though he introduces this concept he quickly discards the idea. "The problem is that the unitary invention principle is simply untrue. The specification and the claims do not describe the same thing in different ways. They describe entirely different concepts with only tenuous relation to each other. The specification describes a single embodiment. The claim describes an idea." Id. at 10. This critique wholly miscomprehends the contents of most patent specifications. First, though most specifications do focus attention on one particular embodiment, they certainly do not describe just one embodiment. It is quite conventional and routine for a specification to describe a large number, even an infinite set of alternative embodiments in addition to the preferred embodiment. See Oskar Liivak, Finding Invention 6-7(Jan. 3, 2012) (unpublished manuscript) (on file with author). Second, as the claims themselves are part of the specification, the claims, especially when they employ structural language, can and often do themselves disclose alternate embodiments. $I d$.

${ }^{72}$ See 35 U.S.C. $\$ 271$ (2006). 
termines what exactly was invented. The disclosure requirements ask applicants to disclose their invention and to distinctly claim it. A claim complies with the requirements of $\S 112$ if the specification can corroborate that the inventor invented the claimed subject matter. ${ }^{73}$ After determining that a claim and its specification have complied with 35 U.S.C. $\$ 112$ II $1-2$, then we can conclude that the claimed subject matter is part of the invention. This ensures that the claims are accurate proxies for the invention. ${ }^{74}$ By way of these statutory provisions, patent law can determine what the invention disclosed in the application is.

Next, patent law must determine if that invention is patentable. This determination is made by 35 U.S.C. $\$ \S 102-03$. If the invention (now determined to be co-extensive with the claimed subject matter) satisfies these requirements, then patent law can conclude that the claimed subject matter also defines a patentable invention, and the claim can be used to define the patent's exclusive rights. ${ }^{75}$ Chart 2 summarizes the process of claim validity under a substantive vision of the invention, and Figure 2 gives a graphical representation of claim scope under this system. The following sections further elaborate on this framework.

${ }^{73}$ See Brief for Oskar Liivak as Amicus Curiae Supporting Defendant-Appellant 12, Ariad Pharms., Inc. v. Eli Lilly \& Co., 598 F.3d 1336 (Fed. Cir. 2010) (No. 20081248), 2009 WL 4616152, at*15 [hereinafter Liivak Brief].

${ }^{74}$ Lefstin, supra note 10 , at 1198.

Even after claiming assumed primary importance, "the Invention" and "the claims" were distinct concepts in American patent law. One could discuss "the invention" in terms of the inventor's physical or mental creation, entirely apart from the question of the scope of the inventor's legal rights. Under such a regime, questions of whether the inventor physically possessed an embodiment of the invention, or whether the inventor mentally possessed the idea behind the invention, are sensible questions. But once the concepts of "invention" and "claim" became essentially synonymous in patent law, the notion of "possessing the invention" became a logical impossibility except as a rephrasing of the ultimate legal conclusion.

Id. (internal citation omitted).

${ }^{75}$ As noted above, these provisions that examine patentable subject matter, utility, novelty, and obviousness explicitly reference the invention. But the previous determinations lead to the conclusion that the claim satisfies 35 U.S.C. $\$ 112$ II $1-2$; these later determinations about patentability can be administered by reference to the claim alone. 


\section{Chart 2: Claim Validity with Substantive Invention}

1. Determine what is the claimed invention:

- Determine what is the invention.

Read the specification and determine what embodiments have been disclosed.

An embodiment is disclosed if a person of skill, after reading the specification, would be directed to and enabled to make and use that embodiment.

- Determine what is the claimed invention.

The purpose of claims is to circumscribe a subset of the disclosed embodiments. The disclosed embodiments are central to (and a fundamental limit on) proper claim interpretation.

- A claim is valid under $\S 112$ II 1-2 if it only circumscribes embodiments disclosed in the specification.

- The set of embodiments fenced by valid claims under \$ 112 II l-2 form the "claimed invention."

2. Determine what portion of the claimed invention is patentable:

- Is the claimed invention new?

- Is the claimed invention nonobvious?

- If so, the claimed invention is patentable. 
Figure 2: Claim Scope with

Substantive Invention

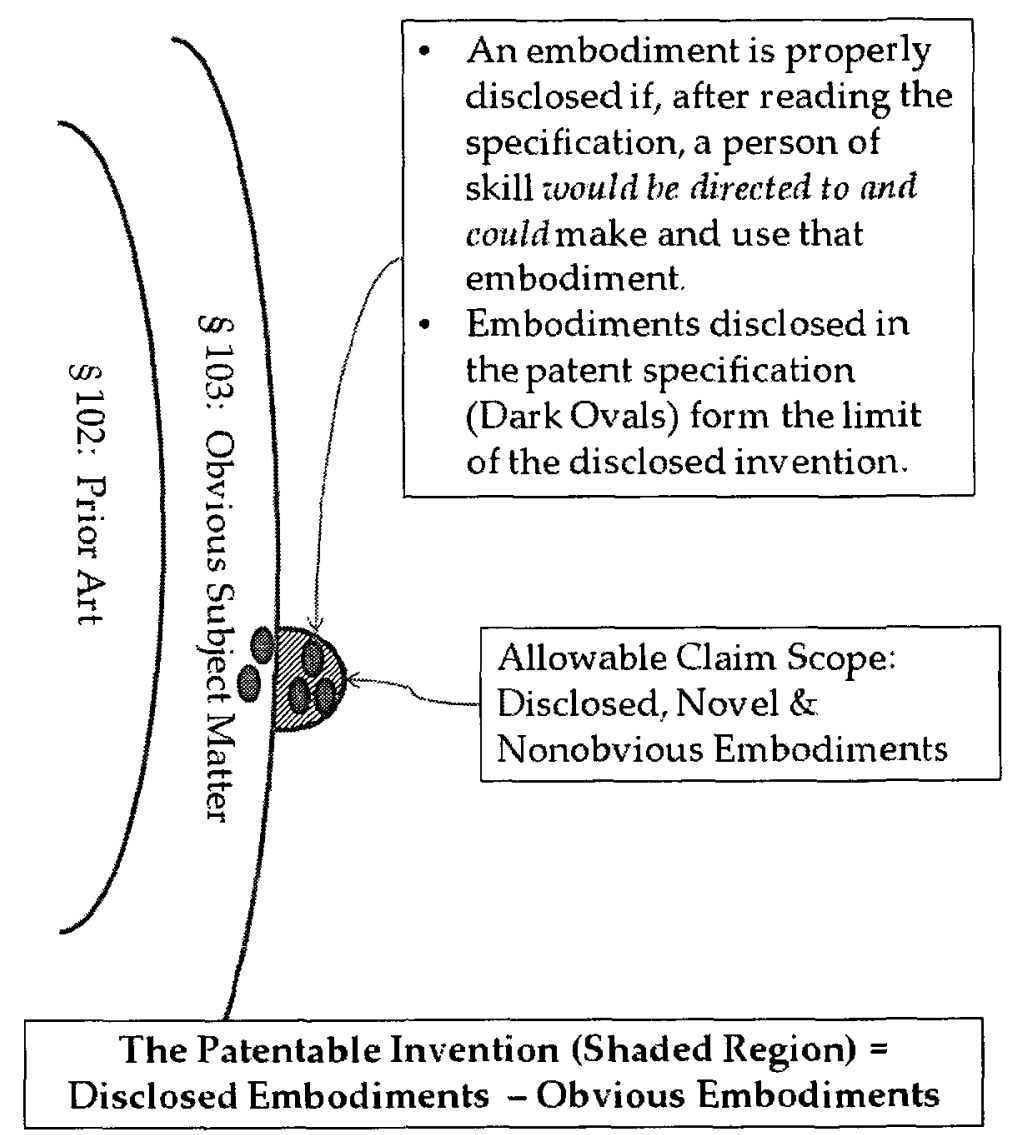

Compared to the current system, such an invention-centric system improves the uniformity of the disclosure requirements because it gives a very natural reading to $\$ 112$ as a whole. It improves uniformity in claim construction because it gives claims contextual meaning. Claims are not written to directly delineate the boundaries of exclusion. ${ }^{76}$ Claims highlight subsets of the embodiments disclosed in the specification. And knowing why the claims were written, judges can then turn to the specification to determine which subset the inventor intended each claim to delineate. This aids uniformity

${ }^{76}$ The grant of exclusion does not directly mention claims; instead, it references the "patentable invention." See id. $\$ 271$ (a). 
and precision in claim interpretation. Claims still aid in marking the boundaries of exclusion but they do so indirectly. Exclusion extends to the patented invention and the claims are tools that help us pinpoint the contents of the patented invention.

This Part will proceed by first elaborating on the support for this substantive view of the invention. It will then outline the overall patent system that this view produces and show that, in this view, disclosure serves the important purpose of corroborating that the applicant did indeed invent the claimed subject matter. Importantly, exclusion is thus limited to subject matter actually invented by the inventor.

\section{A. The Invention Is the Set of Embodiments Conceived by the Inventor}

The invention, " $[t]$ he thing patented[,] is the particular means devised by the inventor by which [a] result is attained." Importantly, the desired result, the "object" of the invention, is not the invention itself. $^{78}$ The invention is the inventor's own specific way of solving some relevant problem. An inventor can claim "the exclusive right to use the means he specifies to produce the result or effect he describes, and nothing more."

The Supreme Court and patent law generally have further refined this by turning to the notion of conception. In 1854, the Court described ' $[t]$ he 'inventor,' in patent law, [a]s the person or persons who conceived the patented invention." ${ }^{, 80}$ More recently the Supreme Court has held that "the word 'invention' in the Patent Act unquestionably refers to the inventor's conception." ${ }^{, 81}$ Likewise one of the most influential treatises in patent law emphasizes this important link, stating, "An inventor, in the meaning of the Constitution, is one who has himself conceived the fundamental idea of the invention, and has embodied it in tangible materials. To him and to him only can a patent lawfully be granted."

Other references to inventing or inventor in patent law already focus on conception. For inventorship, patent law determines who invented an invention based on conception, as "[c]onception is the

77 Electric R.R. Signal Co. v. Hall Railway Signal Co., 114 U.S. 87, 96 (1885).

Id.

O'Reilly v. Morse, 56 U.S. 62, 119 (1854).

${ }^{80}$ Collar Co. v. Van Dusen, 90 U.S. 530, 563-64 (1874).

${ }^{81}$ Pfaff v. Wells Elecs., 525 U.S. 55, 60-61 (1998).

821 William C. Robinson, THe LAW OF PATENTS FOR USEFUl INVENTIONS $\$ 57$, at 91 (1890). 
touchstone of inventorship." ${ }^{83}$ For priority determinations, patent law determines when an inventor invents based on conception. ${ }^{84}$ Consistent with this usage, determining what was invented should also begin by looking to the inventor's conception. As noted in O'Reilly $v$. Morse, when the Court turned to "ascertain and settle, what is the thing which was invented," the Court instructed that "to this end it will be most convenient to begin at its conception.",85

In particular, conception elaborates on the notion of the inventor's specific means for solving some problem. "Conception is the 'formation in the mind of the inventor, of a definite and permanent idea of the complete and operative invention, as it is hereafter to be applied in practice."” In accord with the discussion above, "[i]t is not sufficient that the result to be obtained be conceived, but it is required that there be conceived and disclosed the means provided to accomplish that result." ${ }^{, 7}$

Importantly, conception is complete when "[a]ll that remains to be accomplished, in order to perfect the act or instrument, belongs to the department of construction, not invention., ${ }^{88}$ It is complete "when [the idea] has assumed such shape in the mind that it can be described and illustrated; when the inventor is ready to instruct the mechanic in relation to putting it in working form. ${ }^{89}$ A conception is complete and capable of being reduced to practice when an inventor is able to tell the ordinary mechanic both what is the specific, complete invention as well as how to make and use that invention.

In their casebook, John Duffy and Robert Merges emphasize that "conception" in patent law demands rigor:

There must be a "definite" and "permanent" idea of the "complete" and "operative" invention. Conception does not occur until the inventive idea is "crystallized in all of its essential attributes and becomes so clearly defined in the mind of the inventor as to

${ }^{83}$ Burroughs Wellcome Co. v. Barr Labs., Inc., 40 F.3d 1223, 1227-28 (Fed. Cir. 1994).

${ }^{84}$ See Marconi Wireless Tel. Co. v. United States, 320 U.S. 1, 34-35 (1943) ("It is well established that as between two inventors priority of invention will be awarded to the one who by satisfying proof can show that he first conceived the invention.").

${ }^{85} 56$ U.S. 62, 68 (1854).

${ }^{86}$ Hybritech Inc. v. Monoclonal Antibodies, Inc., 802 F.2d 1367, 1376 (Fed. Gir. 1986)(quoting 1 William C. RoBinson, The LAW OF PATENTS 532 (1980)); see also Field v. Knowles, 183 F.2d 593, 611 (C.C.P.A. 1950).

${ }^{87}$ Field, 183 F.2d at 691.

${ }^{88}$ Mergenthaler v. Scudder, 11 App. D.C. 264, 276 (D.C. Cir. 1897).

${ }^{89}$ Cameron \& Everett v. Brick, 1871 Dec. Comm'r Pat. 89, 90. 
be capable of being converted to reality and reduced to practice by the inventor or by one skilled in the art."

The Federal Circuit has held that "[c]onception requires both the idea of the invention's structure and possession of an operative method of making it." ${ }^{\text {91 }}$ For example, in Board of Education ex rel. Florida State University v. American Bioscience, Inc., the Federal Circuit determined that a researcher could not be included as an inventor when he had not conceived of the claimed compound itself but had only conceived of a generalized method by which a person of skill in the art, if asked to synthesize the claimed compound, could do so.

As used here, conception provides a vehicle for determining what was invented. On first impression, it may not seem so hard to point out what the inventor created. After all, the inventor built her new mousetrap or created her new drug, and is that not her invention? ${ }^{93}$ Indeed the inventor's actual physical creation will be something she conceived, but it has long been rightly thought that the invention can and should, in many cases, extend further than the physical embodiment actually built and should embrace some more abstract notion. ${ }^{94}$ The invention is the set of all of the embodiments that the inventor has invented. That is, the invention is the set of embodiments conceived by the inventor in enough detail so that each of those embodiments is capable of being actually reduced to practice. This abstract concept, this collection of embodiments, is often much larger than just the embodiments that are actual reduced to practice. Inventing some non-zero number of embodiments (either actually or constructively reduced to practice) is a prerequisite for starting the patent procurement process. ${ }^{95}$ In addition, that set of

90 Robert Patrick Merges \& John Fitzgerald Duffy, Patent Law and Policy: CASES AND MATERIALS 450 (4th ed. 2008) (quoting Brown v. Barbacid, 2765 F.3d 1327 (Fed. Cir. 2002)).

${ }^{91}$ Amgen, Inc. v. Chugai Pharm. Co., 927 F.2d 1200, 1206 (Fed. Cir. 1991); see also Oka v. Youssefyeh, 849 F.2d 581, 583 (Fed. Cir. 1988).

92333 F.3d 1330, 1341-42 (Fed. Cir. 2003); see also Fiers v. Revel, 984 F.2d 1164 (Fed. Cir. 1993).

${ }^{93}$ In patent law not every patentable invention is actually reduced to practice. U.S. patent law also allows what is known as constructive reduction to practice. When the patent applicant describes an invention in enough detail to satisfy the disclosure requirements, then patent law describes the invention as being constructively reduced to practice. See Donald Chisum, Chisum on Patents $\$ 10.05$ (2008).

${ }^{94}$ Tilghman v. Proctor, 102 U.S. 707, 708 (1880) ("[Tilghman's patent] must be sustained as a patent for a process, and not merely for the particular mode of applying and using the process pointed out in the specification.").

${ }_{95}$ It is quite similar to the "ready for patenting" standard announced in Pfaff $v$. Wells, 525 U.S. 55 (1998). 
invented embodiments forms a fundamental and substantive limit to the exclusive rights that may ultimately emerge from the patent system.

\section{B. Substantive Invention and a Coherent Framework for Patent Law}

Applying this substantive vision of the invention, a coherent patent system emerges. It leads to a patent system in which validity is divided into two sections. ${ }^{96}$ As stated above, patent law must determine if the patent application contains a "patentable invention." This entails two distinct determinations. First, determining what was invented. And then, determining if (or what portion of) the invention is patentable. The first determination is made by 35 U.S.C. $\S 101$ in concert with 35 U.S.C. $\S 112$ II 1-2. Section 101 is mainly a threshold question asking if anything at all has been invented and if that invention falls into one of the statutory classes of patentable subject matter. If something has been invented then 35 U.S.C. $\$ 112$ II $1-2$ answers in more detail what was in fact invented..$^{98}$ Next, patent law must determine if that invention is patentable. This determination is made by 35 U.S.C. $\$ \S 102$ and 103 . If the invention is patentable, then the applicant receives exclusive rights over that invention. This section explores the details of these two determinations.

1. Section $101 \& 112$ II 1-2: Determining What Is the Invention

Together $\S 101$ and $\S 112$ allow patent law to determine what was invented. Section 101 is a threshold question that simply asks if any embodiment has been invented that fits the listed types of patentable subject matter while $\S 112$ provides the more detailed analysis of what exactly was invented.

To understand the proper role for the disclosure requirements of $\S 112$ II $1-2$, it is best (at first) to look at them from the perspec-

${ }^{96}$ See 35 U.S.C. chs. $10 \& 11$ (2006).

${ }^{97}$ See id. $\$ 271$.

${ }_{98}$ In this article 35 U.S.C. $\$ 101$ is grouped with $\S 112$. A more thorough discussion of $\$ 101$ is beyond the scope of this Article, and it is included here primarily for the sake of completeness. But note that this particular grouping could be further explored to help explain things like the strong overlap between $\S 101$ utility and $\$ 112$ enablement based utility. Similarly the grouping can provide a needed link to explain the overlap and resulting confusion surrounding classification of cases like O'Reilly v. Morse, 56 U.S. 62, 120-21 (1854). This case is exemplary of cases that are alternatively referred to as patentable-subject-matter cases or enablement cases. By grouping $\$ 101$ and $\$ 112$ together with the unified purpose of determining what was invented, patent law may be able to provide a more coherent understanding of their relationship and overall meaning. 
tive of an inventor applying for a patent. Starting with Chapter 11 of 35 U.S.C. entitled "Application for Patent," an applicant sees that $\S$ 111 requires an application to "include a specification as prescribed by section 112 of this title; a drawing ... and an oath by the applicant as prescribed by section 115." ${ }^{99}$ As to the oath, it requires the applicant to swear that "he believes himself to be the original and first inventor of the process, machine, manufacture, or composition of matter, or improvement thereof, for which he solicits a patent." ${ }^{100}$ The oath requires the inventor to swear to have conceived the invention "for which he solicits a patent." ${ }^{\text {"101 }}$ In other words, the applicant can only seek exclusive rights over subject matter that he himself created and that exists in his mind as a "definite," "permanent," "complete," and "operative" form with enough detail that a person of skill can be "instructed ... to put[] it in working form."

After reading about the oath, the inventor turns to $\S 112$ I 1 . There the applicant finds quite familiar language. It requires that the application must contain a specification that

shall contain a written description of the invention, and of the manner and process of making and using it, in such full, clear, concise, and exact terms as to enable any person skilled in the art to which it pertains, or with which it is most nearly connected, to make and use the same.

This language mirrors the language for a completed conception. The inventor sees two things that need to be included: a written description of the invention, and the manner and process of making and using the invention. And the provision instructs that this description be in enough detail so that it "enable[s] any person skilled in the art ... to make and use the [invention]." If indeed an inventor has a completed conception in mind (as he has sworn in the oath), then satisfying the requirement of $\S 112 \mathbb{I} 1$ is quite easy. The applicant is simply asked to write down this already existing completed conception.

See id. $\$ 111$.

${ }^{100}$ See id. $\$ 115$.

${ }^{101} I d$

${ }^{102}$ Cameron \& Everett v. Brick, 1871 Dec. Comm'r Pat. 89, 90 (1871).

${ }^{103} 35$ U.S.C. $\S 112$ I 1 . As suggested earlier, this article is setting aside the best mode requirement of $\mathbb{I} 1$.

${ }^{104} I d$.

${ }^{105}$ See Liivak Brief, supra note 73, at * 12 ("[Section] 112 quite reasonably requires the patent applicant to simply write down that mental conception. This converts the subjective inquiry of whether the claimed subject matter was conceived by the inven- 
The applicant then turns to I 2 of $\S 112$ and sees that it instructs the applicant to "conclude [the specification] with one or more claims particularly pointing out and distinctly claiming the subject matter which the applicant regards as his invention." ${ }^{106}$ This is also relatively clear in the context of a substantive vision of the invention and $\S 112$ If 1 . Having disclosed a set of embodiments, along with how to make and use them, the applicant is instructed to distinctly claim the embodiments "for which he solicits a patent ..."107 in part to avoid confusing the embodiments themselves with the description of how to make and use those embodiments. ${ }^{108}$ The claims are written attempts to circumscribe varying subsets of the embodiments disclosed in the specification.

Section 112 I 2 defines the subject matter for which the applicant seeks a patent. By way of the oath in $\S 115$, the applicant swears to be the inventor of that subject matter. And as required by $\S 112$ I 1 , the specification must contain enough detail to serve as proof that the inventor did indeed invent the claimed subject matter. The specification provides proof that (as of the filing date of the patent application) the inventor conceived the claimed subject matter in enough detail so that a person of skill could make and use the claimed subject matter. When courts now consider conception in the context of inventorship or priority, they "require corroborating evidence." ${ }^{109}$ Section 112 II 1 has a similar coherent purpose. It simply asks whether the specification can objectively corroborate that the patentee conceived and invented the claimed subject matter. ${ }^{110}$ When an applicant can satisfy these requirements, then we can conclude that the claimed subject matter has been invented by the applicant. It allows us to conclude that the claimed subject matter is an accurate and precise proxy for the invention.

\footnotetext{
tor into the objective inquiry of whether the specification can corroborate the invention of the claimed subject matter.").

${ }^{106} 35$ U.S.C. $\$ 112 \llbracket 2$ (2006).

${ }^{107}$ Id. $\$ 115$.

108 The trouble is that patent law allows patents on "process[es], machine[s], manufacture [s], or composition [s] of matter." Id. $\$ 101$. See generally Lutz, supra note 18.

${ }^{109}$ Burroughs Wellcome Co, v. Barr Labs., Inc., 40 F.3d 1223, 1228 (Fed. Cir. 1994).

${ }^{110}$ Liivak Brief, supra note 73 , at $* 32$.
} 
2. Sections $102 \& 103$ : Determining If the Invention Is Patentable

The next step is to determine if the claimed invention is patentable. Again looking at the chapter titles within 35 U.S.C., a patent examiner finds Chapter 10, entitled "Patentability of Inventions." The Chapter includes $\S \S 102$ and 103, which require the invention to be new, nonobvious, and useful patentable subject matter. ${ }^{111}$ For those requirements, $\S \S 102$ and 103 refer in general to the invention but they also refer to the claimed subject matter. ${ }^{112}$ Having satisfied $\S$ 112 II 1-2, patent law can conclude indeed that the subject matter claimed by the inventor is at least the subject matter invented and disclosed by the inventor. Only at this point is there no practical difference between the invention and the claimed subject matter. In other words, after satisfying $\$ 112$ II $1-2$, references to the invention in $\S \S 102$ and 103 can then be safely replaced by the claimed subject matter. If a claim satisfies these requirements, then patent law concludes that the claim circumscribes subject matter that is part of the patentable invention and the applicant can be granted exclusive rights over that subject matter.

\section{Limiting the Patent Grant to the Conceived Invention}

In addition to direct statutory references, there are other very compelling reasons to adopt the substantive view. As suggested in Part II, the cult allows claims that extend well beyond the subject matter disclosed or even contemplated by the inventor. In contrast, the patent system that emerges from the substantive view inherently limits patent claims to subject matter that was conceived and disclosed by the inventor. As shown here, this is not just a statutory limit. One of patent law's few constitutional limits is that the exclusive rights can extend only to the work of the inventor. In other words, the grant of exclusivity can extend only to subject matter conceived by the inventor. The cult's patent system violates this limit while the substantive invention system inherently respects it.

The Supreme Court has held on numerous occasions that, at most, inventors can claim only that which they themselves invented. "[The patentee] can lawfully claim only what he has invented ...."114 " $[\mathrm{I}] \mathrm{t}$ is clear that the party cannot entitle himself to a patent for more

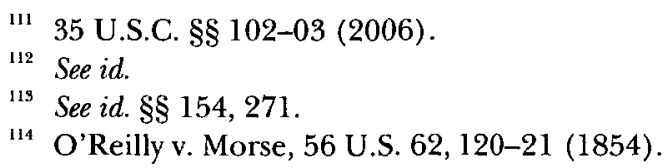


than his own invention." ${ }^{115}$ These are not isolated statements. ${ }^{116}$ And this limit has teeth. For example, the Court in O'Reilly concluded that "[i]n fine, [Morse] claims an exclusive right to use a manner and process which he ... had not invented.... The court is of opinion that the claim is too broad, and not warranted by law." ${ }^{117}$ In short, "[a patentee] can lawfully claim only what he has invented and described, and if he claims more his patent is void."

Such repeated emphasis on this limit is not surprising. It stems directly from the constitutional mandate in art. I, $\S 8, \mathrm{cl} .8$ to grant exclusive rights only to inventors for their discoveries. ${ }^{119}$ In other words, the subject matter claimed by a patent is limited to subject matter that is original to the inventor, subject matter that was in fact invented by the inventor. ${ }^{120}$ As put by Chief Justice Marshall, "it cannot be doubted that the settled purpose of the United States has ever been, and continues to be, to confer on the authors of useful inventions an exclusive right in their inventions for the time mentioned in their patent." ${ }^{121}$

${ }^{115}$ Evans v. Eaton, 20 U.S. 356, 430 (1822).

116 See Ensten v. Simon, Ascher \& Co., 282 U.S. 445, 452-53 (1931) (describing the "principle which forbids a patentee to assert a right to more than he has actually invented") (quoting 2 RoBINSON, supra note 86, at 284); Agawam v. Jordan, 74 U.S. 583, 602 (1869) ("No one is entitled to a patent for that which he did not invent . . .."); Morey v. Lockwood, 75 U.S. 230, 240 (1869) ("Several objections are taken to this reissued patent; among others, and which is the most material, that the claim is broader than the invention."); see also O'Reilly, 56 U.S. at 120 (describing "the evil ... if [a patentee] claims more than he has invented, although no other person has invented it before him"), Wyeth v. Stone, 30 F. Cas. 723, 727 (C.C.D. Mass. 1840) (No. 18,107 ) (Story, J.) ("A claim broader than the actual invention of the patentee is, for that very reason, upon the principles of the common law, utterly void, and the patent is a nullity.").

${ }^{117}$ O'Reilly, 56 U.S. at 113.

118 Id. at 121; see also Mackay Radio \& Tel. Co. v. Radio Corp. of Am., 306 U.S. 86, 98 (1939) (holding that if claims exceed the described invention, then those "claims ... must fail").

119 See U.S. CONST. art. I, § 8, cl. 8.

${ }^{120}$ See In re Trade-Mark Cases, 100 U.S. 82, 93-94 (1879) (holding that art. I $\$ 8$ Cl. 8 requires originality); R. CARL MOY, MOY's WALKER ON PATENTS $\$ 1: 15$ (4th ed. 2007) ("[In view of the Trade-Mark Cases] it appears that Congress's authority under the intellectual property clause is limited to the protection of subject matter that is original to the grantee."); see also Burrow-Giles Lithographic Co. v. Sarony, 111 U.S. $53,57-58$ (1888) ("An author [of a copyright] in [the constitutional] sense is he to whom anything owes its origin; originator; maker . . .." (internal quotation marks and citations omitted)).

${ }^{121}$ Grant v. Raymond, 31 U.S. 218, 241 (1832) (Marshall, C.J.) 
As discussed earlier, despite this clear limit, the cult appears to have either forgotten about it ${ }^{122}$ or it has decided to ignore it. In modern patent law, "[c]laims are frequently a far cry from what the inventor invented." The "Patent Office typically allows patent claims that are of much broader scope than what is actually disclosed in a patent application." ${ }^{124}$ This standard does not prevent claims from reaching non-original subject matter. Indeed, in modern patent law it is commonplace for commentators to state that patent claims should routinely extend beyond the embodiments disclosed in the specification. As inventorship and originality are constitutionally rooted requirements, the fact that the trivial theory of invention allows for violations of this requirement should be a clear signal that the trivial vision is simply the incorrect interpretation. ${ }^{125}$

In contrast, the substantive theory of the invention leads to a different limit on patent claims, one that respects this constitutional limit. ${ }^{126}$ The substantive invention begins with the subject matter actually conceived by the inventor. Of that, some subset is described in the patent specification. Of that, some subset is claimed. Of that described, claimed invention, some subset is found to be patentable. Ultimately the patentable invention (i.e., the resulting grant of exclusive patent rights) extends only to the patentable portions of the claimed, described invention. This necessarily means that the exclusive rights extend to a subset of what was originally invented by the inventor. This inherently limits the exclusive rights to subject matter original to the inventor. As stated by the Supreme Court, "[The patentee] can lawfully claim only what he has invented and described,

${ }^{122}$ See generally Oskar Liivak, The Forgotten Originality Requirement: A Constitutional Hurdle for Gene Patents, 87 J. PAT. \& TRADEMARK OFF. SOC'Y 261 (2005).

${ }^{129}$ MUELLER, supra note 24, at 67 (quoting Judge Giles S. Rich).

124 Sichelman, supra note 67, at 356.

${ }^{125}$ See Solid Waste Agency of N. Cook Cnty. v. U.S. Army Corps of Eng'rs, 531 U.S. 159,173 (2001) ("The Court will construe the statute to avoid [raising serious constitutional problems] unless such construction is plainly contrary to the intent of Congress." (citing Edward J. DeBartolo Corp. v. Fla. Gulf Coast Bldg. \& Constr. Trades Council, 485 U.S. 568, 575 (1988))). In addition, note that for this issue of interpretation, Congress's broad powers under the Commerce Clause are not relevant. The current patent statute was explicitly enacted under the powers granted by the Patent and Copyright Clause. See S. REP. No. 82-1979 (1952), as reprinted in 1952 U.S.C.C.A.N. 2394, 2396.

${ }^{126}$ This provides another important reason to argue for the substantive interpretation over the cult's view, as the substantive view inherently respects this limit while the cult's view does not. 
and if he claims more his patent is void." ${ }^{127}$ And if claims exceed the described invention, those "claims . . . must fail."

As suggested above, the trivial theory of invention limits claims to subject matter that a person of skill could make and use based on the patent specification if asked to. In contrast, the substantive view limits claims to subject matter that a person of skill would make and use based on the patent specification. In the substantive view, the disclosure inquiry is not stated as a leading question. Instead, a person of skill is given the patent specification and asked: Based on this document, what things would you construct? That set of embodiments, that a person of skill would construct, forms the invention disclosed by the specification, and the patent claims are limited to those embodiments.

Justice Story described the disclosure requirements in this way:

It is therefore argued, that if the specification be materially defective, or obscurely or so loosely worded, that a skillful workman in that particular art could not construct the machine, it is a good defense against the action, although no intentional deception has been practiced. And this is beyond all question the doctrine of the common law; and it is founded in good reason; for the monopoly is granted upon the express condition, that the party shall make a full and explicit disclosure, so as to enable the public, at the expiration of his patent, to make and use the invention or improvement in as ample and beneficial a manner as the patentee himself. If therefore it be so obscure, loose, and imperfect, that this cannot be done, it is defrauding the public of all the consideration, upon which the monopoly is granted. ${ }^{129}$

A few years later, in The Telephone Cases, the Supreme Court similarly stated that the validity of a patent specification asks whether

[a] good mechanic, of proper skill in matters of the kind, can take the patent, and, by following the specification strictly, can, without more, construct an apparatus which, when used in the way pointed out, will do all that it is claimed the method or process will do. ${ }^{130}$

In other words, under the substantive view, the specification describes the invention and the claims circumscribe that same invention. And the only embodiments that can be claimed are those that a person of

${ }^{127}$ O'Reilly v. Morse, 56 U.S. 62, 121 (1853).

${ }^{128}$ Mackay Radio \& Tel. Co. v. Radio Corp. of Am., 306 U.S. 86, 98 (1939).

${ }^{129}$ Whittemore v. Cutter, 29 F. Cas. 1120, 1122 (C.C.D. Mass. 1813) (No. 17,600); see Turner v. Winter, (1787) 99 Eng. Rep. 1274 (K.B.); The King v. Arkwright, Dav. Pat. Case 106 (1785); see also Janis, supra note 64, at 55-56.

iso 126 U.S. 1, 536 (1888) (emphasis added). 
skill would make and use based on the patent specification. ${ }^{131}$ Those embodiments are original to the inventor. The substantive vision of the invention leads to a disclosure requirement that inherently respects the foundational limits of the patent system.

\section{The Cult and Its Misreading of Precedent}

This section returns to the Supreme Court cases that have been quoted in support of the cult's vision of the invention. As shown here, reading those quotes with more context shows that those cases in fact support the substantive vision and the cult has simply misinterpreted them.

The cult has supported its trivial view of the invention by citation to Supreme Court cases such as McClain v. Ortmayer ${ }^{132}$ and Aro Manufacturing $v$. Convertible Top. ${ }^{138}$ Though certainly short quotes from these cases seem to indicate support for the trivial view, more comprehensive passages from these same sections show that these cases are completely consistent and, in fact, instead reinforce the substantive view of the invention. In McClain, the Supreme Court stated that

[n]othing is better settled in the law of patents than that the patentee may claim the whole or only a part of his invention, and that if he only describe and claim a part, he is presumed to have abandoned the residue to the public. The object of the patent law in requiring the patentee to "particularly point out and distinctly claim the part, improvement or combination which he claims as his invention or discovery," is not only to secure to him all to which he is entitled, but to apprise the public of what is still open to them. The claim is the measure of his right to relief, and while the specification may be referred to limit the claim, it can never be made available to expand it."

Similarly in Aro, the Supreme Court stated that

[s] ince the patentees never claimed the fabric or its shape as their invention, and the claims made in the patent are the sole measure of the grant, the fabric is no more than an unpatented element of the combination which was claimed as the invention, and the patent did not confer a monopoly over the fabric or its shape.

${ }^{131}$ Sean Seymore has argued along not too dissimilar lines for improved teachings in the patent disclosure. See Sean Seymore, The Teaching Function of Patents, 85 NOTRE DAME L REV. 621 (2010).

${ }^{192} 141$ U.S. 419 (1891).

${ }^{133} 365$ U.S. 336 (1961).

${ }^{134}$ McClain, 141 U.S. at $423-24$

${ }^{135}$ Aro Mfg. Co., 365 U.S. at 339-40. 
Both of these passages demonstrate that statements like "the claims are the sole measure of the grant" are actually quite straightforward statements. In the substantive view, an inventor may invent quite broadly. Of that invention, the inventor may only disclose a limited number of embodiments in the specification. Of those embodiments that are disclosed, the inventor might only claim a subset. With that in mind, the Court is just making the relatively straightforward statement that no matter how broadly you might have invented, only the embodiments that are claimed will need to comply with the validity portions of the patent statute and only the claimed embodiments can be infringed. ${ }^{136}$

Rather than saying that the invention should be defined by the claims, it is better to understand these cases as saying that, no matter what an inventor actually invented, patent law and the courts will only consider what the inventor actually invented, disclosed, and claimed. The Court in Motion Picture Patents Co. v. Universal Film Manufacturing Co. described this relationship between the claims and the invention by stating that "we are convinced that the exclusive right granted in every patent must be limited to the invention described in the claims of the patent."137 In other words, the Supreme Court precedent that is being used to support the trivial vision of the invention better supports (when more of the opinion is read in context) the substantive view.

\section{ON THE BENEFITS OF THE SUBSTANTIVE INVENTION FOR PATENT LAW}

So far, this Article has outlined the cult's trivial vision of the invention and the patent system that emerges from that view and has then introduced the substantive vision of the invention and its patent system. Currently, as a doctrinal matter, modern patent law exists somewhere between these two. As a definitional matter, modern patent law still steadfastly stands by the "bedrock principle" at the heart of the cult. ${ }^{138}$ Yet in a number of important areas, modern patent law is not rigorously following the patent system that would emerge from following that principle. Instead, it is moving toward the system envisioned by the substantive view. As the substantive view is the correct interpretation, this is a good sign, but that move is incomplete. This Part examines two key areas: the disclosure requirements and claim

\footnotetext{
136 This leaves questions about the doctrine of equivalents aside for the moment.

${ }^{137} 243$ U.S. 502, 516 (1917).

${ }_{138}$ Phillips v. AWH Corp., 415 F.3d 1303, 1312 (Fed. Cir. 2005) (en banc).
} 
interpretation. It reviews the position each view would take regarding each of these areas and then it compares those positions against the current state of patent law. The Part then describes how much further patent law needs to move in order to fully come in line with the substantive vision of the invention and the benefits that accrue from making that change.

\section{A. Substantive Invention and Disclosure}

Modern patent law's parsing of the disclosure requirements has proven to be controversial and confusing. Between the two main disclosure sub-tests, enablement is generally seen as "uncontroversial" and the more important of the two. ${ }^{140}$ Yet even with enablement, there is confusion. There is a "split" in Federal Circuit cases over the amount of disclosure required to satisfy enablement. ${ }^{141}$ Some cases state that "enabling any embodiment [within the scope of a claim] satisfies the enablement requirement regardless of the breadth of the claims." ${ }^{142}$ This was described by Robin Feldman as "the one embodiment doctrine." ${ }^{143}$ In contrast, in the unpredictable arts, many cases have held that "a single embodiment might not be sufficient to enable broad claims because [cases dealing with the unpredictable arts] required a correspondingly more detailed disclosure to show that a person of ordinary skill in the art could use or practice the claimed invention." ${ }^{144}$ Recently the Federal Circuit has adopted the more stringent requirements from the unpredictable arts and has applied them in the predictable arts. Now, "disclosing a single embodiment will not automatically satisfy the enablement requirement." ${ }^{145}$ This new full scope requirement for the predictable arts appears irreconcilable with those earlier cases. ${ }^{146}$ Scholarly work has started to question whether it is even possible to satisfy the new "full scope" doctrine

199. Lefstin, supra note 10, at 1152.

140 Id.; see also Enzo Biochem, Inc. v. Gen-Probe Inc., 323 F.3d 956, 982 (Fed. Cir. 2002) (Rader, J., dissenting).

${ }_{141}$ Bernard Chao, Rethinking Enablement in the Predictable Arts: Fully Scoping the New Rule, 2009 STAN. TECH. L. REV. 3, I 7.

${ }^{142}$ Id. II 50; see also Merges \& Nelson, supra note 59, at 845 ("This [enablement] requirement can at times be applied rather loosely: a specification that describes only one working example of an invention but that supplies less guidance on the subject matter at the fringes of a patent's claims is often sufficient.").

${ }^{143}$ Feldman, supra note 60, at 61.

${ }^{144}$ Chao, supra note 141 , I 51.

${ }^{145} \quad$ Id. I 52

146 Id. 
for enablement, ${ }^{147}$ arguing that "a literal application of the 'full scope' rule would invalidate every patent in existence." "To require a specification teach how to build every claimed embodiment is thus to demand the impossible." ${ }^{149}$ This split has yet to be resolved in the courts.

An orthodox application of the cult's vision would support something akin to the one embodiment doctrine. In that sense the more stringent full scope rule appears to back away from strictly adhering to the cult's vision, and indeed, the substantive vision of the invention supports an enablement requirement under which every claimed embodiment must be enabled. Yet current patent law's view on enablement, even in light of the full scope cases, has not reflected a coherent adoption or rejection of either vision of the invention and instead it lies somewhere in the vague no-man's land between these two distinct views.

Similar ambiguity surrounds the written description requirement, the other sub-test for disclosure. Over a decade ago, the Federal Circuit decided Regents of the University of California v. Eli Lilly. ${ }^{150}$ The case applied the written description requirement to original claims and affirmed their invalidity. ${ }^{151}$ As suggested in Part II, this is directly in conflict with the cult's vision for the disclosure requirements. This application of the written description requirement outside the confines of its public notice role has been called "misguided" ${ }^{152}$ and an "unmitigated disaster." ${ }^{153}$ Numerous articles have

147 Lefstin, supra note 10, at 1165-67; see Daniel L. Burk \& Mark A. Lemley, Policy Levers in Patent Law, 89 VA. L. REV. 1575, 1678-80 (2003).

${ }^{148}$ Chiang, supra note 23, at 18.

149 Id. at 19.

150119 F.3d 1559 (Fed. Cir. 1997).

${ }^{151}$ Id. at 1569.

152 Ariad Pharms., Inc. v. Eli Lilly \& Co., 560 F.3d 1366, 1380 (Fed. Cir. 2009) (Linn, J., concurring) (noting that the majority opinion "is supported by our precedent" but arguing that the precedent should be overruled en banc). Jeffrey Lefstin, without saying as much, has argued that generally this opposition to the Eli Lilly written description requirement stems from the cult and its views. See Lefstin, supra note 10, at 1157 ("Hostility to the written description requirement derives fundamentally from the belief that written description is incompatible with the modem claim. The claim is the abstract legal creature at the heart of modem patent law, and the cornerstone of the conceptually ordered system pursued by formalist thinkers. For those who seek a conceptually ordered system of patent law, written description plays no role in a rational modern system ....").

${ }^{153}$ Harris A. Pitlick, The Mutation on the Description Requirement Gene, 80 J. PAT. \& TRADEMARK OFF. SOC'Y 209, 222 (1998). 
criticized the written description. ${ }^{154}$ It is accused of creating "a welter of confused and confusing precedent that not only defies restatement but renders analysis and synthesis distinctly unmanageable., ${ }^{155}$ Commentators worry that it "only allows very narrow patents, so narrow and easily dodged as to be almost worthless." ${ }^{\prime 156}$ In particular, many have worried that the requirement is an industry specific "elevated"157 or "super" ${ }^{158}$ enablement requirement that applies disproportionately in biotechnology, that for biotechnology it threatens to alienate both "business and science communities" as it "no longer reflects the realities of scientific contribution," 159 and "if followed," would be an "unmitigated disaster ... [that] has the potential for causing untold havoc in the biotechnology field." ${ }^{160}$ The overall result is, as put by Robin Feldman, "a wealth of contradictory opinions and unworkable doctrines" $"$ that lack "a comprehensive vision of the problem or how to solve it."

Recently in the en banc opinion for Ariad v. Eli Lilly, the Federal Circuit tried to resolve some of these issues. The court held that the written description requirement applies to original as well as amended claims. ${ }^{163}$ The majority found the requirement in the statutory language that the "specification shall contain a written description of the invention." "The court interpreted that language to require a description that "clearly allow[s] persons of ordinary skill in

${ }^{154}$ See Univ. of Rochester v. G.D. Searle \& Co. Inc., 375 F.3d 1303, 1315-21 (Fed. Cir. 2004) (listing articles critical of the written description requirement); Christopher M. Holman, Is Lilly Written Description a Paper Tiger?: A Comprehensive Assessment of the Impact of Eli Lilly and Its Progeny in the Courts and PTO, 17 ALB. L.J. SCI. \& TECH. 1 (2007); Mark D. Janis, On Courts Herding Cats: Contending with the "Written Description" Requirement (and Other Unruly Patent Disclosure Doctrines), 2 WASH. U. J.L. \& POL'Y 55 (2000).

${ }^{155}$ Harmon, supra note 22, at 154.

${ }_{156}$ Michael Delmas Plimier, Genentech, Inc. v. Novo Nordisk $\mathcal{E}$ University of California v. Eli Lilly and Co., 13 BERKELEY TECH. L.J. 149, 161 (1998).

${ }^{157}$ Arti K. Rai, Intellectual Property Rights in Biotechnology: Addressing New Technology, 34 WAKE FOREST L. REV. 827, 835 (1999).

158 Burk \& Lemley, supra note 147, at 1653.

159 Mueller, supra note 34 , at 615-16.

${ }^{160}$ Pitlick, supra note 153, at 222.

161 Robin Copper Feldman, Rethinking Patenting in Biospace, 79 S. CAL. L. REV. 1, 4 (2005).

162 Id. at 3-4.

${ }^{163}$ Ariad Pharms., Inc. v. Eli Lilly \& Co., 598 F.3d 1336, 1351 (Fed. Cir. 2009) ("Neither the statute nor legal precedent limits the written description requirement to cases of priority or distinguishes between original and amended claims.").

164 35 U.S.C. $\$ 112$ I 1 (2006). 
the art to recognize that [the inventor] invented what is claimed."'165 Alternatively, the majority held that "the test for sufficiency is whether the disclosure of the application relied upon reasonably conveys to those skilled in the art that the inventor had possession of the claimed subject matter as of the filing date." ternate tests, the court admitted that "possession ... has never been very enlightening" ${ }^{167}$ and it concluded with a summation that relied more on the former test. The court held that,

whatever the specific articulation, the test requires an objective inquiry into the four corners of the specification from the perspective of a person of ordinary skill in the art. Based on that inquiry, the specification must describe an invention understandable to that skilled artisan and show that the inventor actually invented the invention claimed.

Though Ariad certainly moved patent law away from a pure cult vision for disclosure and closer to the substantive vision of invention, an explicit adoption of the substantive vision did not occur, and there remain important unresolved issues.

First, the opinion "reaffirm[ed] that $\S 112$, first paragraph, contains a written description requirement separate from enablement." ${ }^{169}$ In other words, enablement presumably does something apart from written description. To show that "the inventor actually invented the invention claimed"170 requires showing both conception of the invention itself as well as how to make and use it. Both need to be disclosed in enough detail so that any person of skill in the art could make and use the invention. In order to comply with the Ariad test for written description, the specification must, as part of that test, satisfy the enablement test. In short, the en banc Federal Circuit in Ariad held that there was a separate written description requirement apart from enablement; yet after Ariad, there appears to be no enablement requirement separate from written description.

In addition to this issue, the Ariad opinion tied its written description requirement only to the statutory language that the specification "contain a written description of the invention." The trouble

${ }^{165}$ Ariad Pharms., 598 F.3d at 1351 (second alteration in original) (quoting VasCath Inc. v. Mahurkar, 935 F.2d 1555, 1563 (Fed. Cir. 1991)).

160 Id.

167 Id.

168 Id.

169 Id. at 1340 .

$170 \quad$ Id. at 1351.

17 Ariad Pharms., 598 F.3d at 1344. 
is that, in my opinion, it then requires an awkward reading of the rest of the statute. In that view, the enablement requirement is then provided by the language requiring that the specification "shall contain a written description ... of the manner and process of making and using [the invention], in such full, clear, concise, and exact terms as to enable any person skilled in the art ... to make and use the [invention]." tute, and Judge Rader and Judge Linn, the dissenters-in-part in Ariad, pounced on that issue:

This court, however, calves the "written description of the invention" language out of its context in the rest of the paragraph. In this court's strained reading, the prepositional phrases that follow apply only to a "written description ... of the manner and process of making and using" the invention, not to a "written description

Though Judge Rader and Judge Linn are likely the strongest and most vocal current supporters for the cult of the claim, I agree with them on this parsing of the statute, yet I very much disagree with their interpretation. As shown above, with a substantive vision of the invention, 35 U.S.C. $§ 112 \mathbb{I I ~} 1-2$ as a whole requires that the specification can establish that the applicant invented and disclosed the claimed subject matter in the specification. With this broad holistic rule, we do not have to break $\S 112$ I 1 into subtests of enablement and written description.

In fact, Judge Newman in her additional views suggested something similar when she noted that we need not focus so much on the particular subtests:

In my view, the overriding policy of patent systems requires both written description and enablement, and it is less critical to decide which statutory clause applies in a particular case, than to assure that both requirements are met.... As the court debates the relationship between "written description" and "enablement," let us not lose sight of the purpose of Section $112 .{ }^{174}$

Indeed, such worries about parsing the disclosure requirements have existed for a long time. In 1854, the leading treatise of the time commented that "the statute requisites for a good specification run so

172 Id. at 1343; see also 35 U.S.C. $\$ 112 \mathbb{I} 1$ (2006). As suggested earlier, this Article is ignoring the best mode requirement of $\mathbb{1} 1$.

${ }_{179}$ Ariad Pharms., 598 F.3d at 1362 (Rader, J., dissenting in part and concurring in part); see also id. at 1367 (Linn, J., dissenting in part and concurring in part).

174 Id. at 1359 (majority opinion). 
much into each other, in their nature and character, and are so blended together that it is difficult to treat of them separately." ${ }^{, 175}$

The substantive view of the invention leads to a natural solution of all these issues as it does not need to separate enablement or written description but instead gives purpose and meaning to the whole of the disclosure requirement in $\S 112 \mathbb{I} 1 .^{176}$ The disclosure requirement ensures that the specification can corroborate that the inventor did indeed invent the claimed subject matter. That gives a clear overarching purpose to $\S 112$ II 1 . Certainly patent law can elaborate on the details of the requirements by generally putting the description of the embodiments themselves under the written description heading while putting their making and use under enablement.

\section{B. Substantive Invention: Giving Claims Contextual Meaning}

In addition to problems with disclosure, there is growing evidence that claim interpretation is just not a uniform process. ${ }^{17}$ "[C] ourts seem unable to agree on what particular patent claims mean." ${ }^{178}$ The promise of certainty made by peripheral claiming appear "to be an illusion." system "isn't working." "180

In recent years the Federal Circuit has tried to make claim interpretation more predictable. One such attempt, Phillips v. AWH Corp., aimed to resolve the proper methodology for interpreting claims." The controversy developed because of a split in the Federal Circuit's claim interpretation case law. One line of cases emphasized the specification as the most important source for resolving claim interpretation issues. Meanwhile, another line of cases, most notably Texas Digital Systems, Inc. v. Telegenix, Inc., ${ }^{182}$ developed. It voiced concern over "reading limitations from the specification into the claim[s],"183 and put a heavy emphasis on the use of dictionaries rather than turning

${ }^{175}$ George Ticknor Curtis, The LAW OF PATENTS 189 (1854).

${ }^{176}$ Throughout this Article, disclosure requirement, or $\S 112 \mathbb{1} 1$, has meant to include the language associated with written description and enablement only. Best mode is not included in these discussions.

177 Daniel L. Burk \& Mark A. Lemley, Fence Posts or Sign Posts-Rethinking Patent Claim Construction, 157 U. PA. L. REv. 1743, 1744 (2009).

${ }^{178} I d$.

179 Id. at 1745 .

${ }_{180}$ Id. at 1744 .

181415 F.3d 1303 (Fed. Cir. 2005) (en banc).

182 308 F.3d 1193 (Fed. Cir. 2002).

183 Phillips, 415 F.3d at 1323. 
immediately to the specification. The Texas Digital line of cases worried that if the specification granted unfettered control over the claim interpretation process, then if a patentee described only one or a very limited number of specific embodiments, the patentee's claims would be similarly limited to those specific embodiments. ${ }^{184}$ The Texas Digital line of cases is closely related to the cult's view of claims and to its support for the one embodiment rule.

Phillips resolved this immediate intra-circuit controversy. The court rejected the Texas Digital approach of relying primarily on dictionary plain meaning for claims, and it described the proper sources for information for claim interpretation and the relative weight and priority among them. After Phillips, it is clear that amongst sources the specification is the most important in claim interpretation. The Phillips court held that "claims 'must be read in view of the specification, of which they are a part.' ... [T] he specification 'is always highly relevant... [and] [u]sually, it is dispositive; it is the single best guide to the meaning of a disputed term." "185 Phillips downgraded the importance of dictionaries and treatises, rejecting the Texas Digital view that "the use of the dictionary may extend patent protection beyond what should properly be afforded by the inventor's patent.",186

In other words, Phillips settled the immediate methodological conflict, and indeed its emphasis on the specification signaled a victory for the substantive view of the invention. Yet the victory was far from complete, and indeed there continue to be serious issues in claim interpretation. As Hal Wegner very recently warned, until something is changed, "there will never be clarity in claim construction." ${ }^{187}$ The problem is that Phillips explicitly refused to decide the more fundamental divide that Texas Digital represented. Phillips reaffirmed the dangers, emphasized by Texas Digital, "of reading limitations from the specification into the claim." 188 In other words, it resolved the immediate procedural conflict but it did nothing to resolve the conceptual conflict that had created the procedural conflict. The court acknowledged that reconciling these two "can be difficult,"189 yet ultimately reassured us that the line can be "discerned with reasonable certainty and predictability."

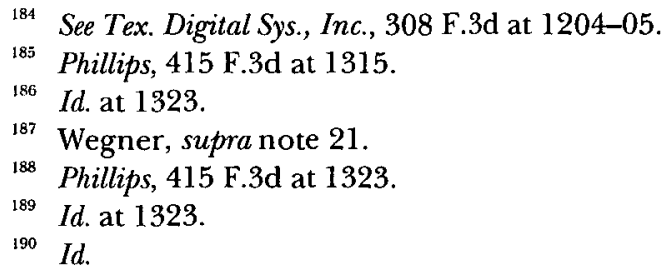


In practice it has proved very hard to distinguish between these two. There appears to be an "inherent tension ... as to whether a statement [in the specification] is a clear lexicographic definition or a description of a preferred embodiment." ${ }^{191}$ This tension between "reading limitations from the specification into the claim" and interpreting claims "in view of the specification" is very closely related to the fight over the disclosure requirements between the one embodiment rule and the rule limiting the claims to embodiments disclosed in the specification. ${ }^{192}$ As this Article emphasizes the correctness of the substantive view, it advocates for choosing the latter rule. In other words, claims must be read in light of the specification, and the claims cannot validly extend to embodiments that were not disclosed in the specification. As argued by Judge Lourie, in a concurrence joined by Judge Newman: "[C]laims need not necessarily be limited to specific or preferred embodiments in the specification, although they are limited to what is contained in the overall disclosure of the specification." ${ }^{193}$ So far, patent law has yet to resolve this conflict.

The problem is that Phillips did not reach the underlying issue of the invention. In fact, whether intentional or not, Phillips walks a fine line that supports both visions of the invention. It reiterates the "bedrock principle" that "the claims of a patent define the invention." But as suggested earlier, this statement is ambiguous. It has often been used to support the cult but it can also be reinterpreted to support the substantive vision. ${ }^{195}$ Indeed, directly following that statement, Phillips follows with a statement that supports either view. It provides some support for the substantive view by stating that "we look to the words of the claims themselves ... to define the scope of the patented invention." ${ }^{196}$ But it immediately follows with a clear

${ }_{191}$ E-Pass Techs., Inc. v. 3COM Corp., 343 F.3d 1364, 1369 (Fed. Cir. 2003); see also LG Elecs., Inc. v. Bizcom Elecs., Inc., 453 F.3d 1364, 1374 (Fed. Cir. 2006), rev'd on other grounds sub nom. Quanta Computer, Inc. v. LG Elecs., Inc., 553 U.S. 617 (2008); Chiang, supra note 23, at 13; Joseph Scott Miller, Enhancing Patent Disclosure for Faithful Claim Construction, 9 LEWTS \& CLARK L. REv. 177, 205 (2005); Robert Unikel \& Douglas Eveleigh, Protecting Inventors, Not Fortune Tellers: The Available Patent Protection for After-Developed Technologies, 34 AIPLA Q.J. 81, 88 n.9 (2006) ("How one can read claims 'in light of the specification' but yet avoid importing limitations from the specification has never been adequately explained, perhaps because these ostensibly contradictory tenets of claim construction cannot be reconciled.").

192 See also Cotropia, supra note 12, at 17-18 (arguing that the disclosure debate and the claim construction debate are closely linked).

193 Phillips v. AWH Corp., 415 F.3d 1303, 1328-29 (Fed. Cir. 2005) (en banc).

$194 \quad$ Id. at 1312.

${ }_{195}$ See supra Part III. D.

196 Phillips, 415 F.3d. at 1312. 
nod to the cult: "The written description part of the specification itself does not delimit the right to exclude. That is the function and purpose of the claims." ${ }^{197}$ In short, this Article argues that, just as with the disclosure requirements, claim interpretation remains an unacknowledged mix of both a trivial and a substantive vision of the invention. It has yet to squarely face and decide this critically important issue. ${ }^{198}$

Patent law should discuss and then adopt the substantive vision of the invention. Though Phillips describes the sources that can be consulted during claim interpretation, it does not tell us what claims are. In the cult's view, they are just the exclusive rights granted by a patent. That definition gives very few contextual clues as to the distinction between correct and incorrect interpretations. Full adoption of the substantive view adds meaning because it tells us why the claims were written. The claims were written to circumscribe differing parts of the invention disclosed in the specification. This tells us what claims are and tells us thus how to interpret them.

In the modern cult-influenced patent system, the claims have no conceptual meaning outside of their definition of the exclusive rights. In the cult's eyes, the claims were written by the applicant only for the purpose of defining their rights to exclude. In later construction of those words, there is little that helps to tell a judge where precisely to draw the line. It is not surprising then that "courts define the scope of legal rights not by reference to the invention but by reference to semantic debates over the meaning of words chosen by lawyers." $" 199$

By emptying the invention of any substantive content, modern patent law has removed meaning from the claims. Claim interpretation is now a meaningless exercise. Interpretation in modern patent law takes the actual words from claim language and replaces them with more words. ${ }^{200}$ Phillips did give a methodology for claim construction. We know what sources to consult, but in a fundamental sense we still do not know what we are doing. We know that claims matter but we do not know what they represent. We still do not have a coherent picture of what the claims represent because in the formalist modern view claims do not represent anything but their function as boundaries for exclusion. ${ }^{201}$ In a recent article, Mark Lemley

\footnotetext{
${ }^{197} I d$.

198 See Cotropia, supra note 12, at 52.

199 Burk \& Lemley, supra note 177, at 1746

200 See id.

201 See MUELLER, supra note 24, at 69-70.
} 
and Dan Burk suggest that patent law should stop "relying on the illusion of peripheral [claiming]" and its promise of uniformity and certainty. ${ }^{202}$ Their concern with the present system is that

we're not often litigating what the inventor did or what her patent should cover, because we are too concerned with what the lawyers did to define what the invention should cover. We have, in other words, taken our eyes off of the ball.

The shift in focus from the invention to the claim language allows both sides to game the process. It permits-and indeed even encourages-over claiming by patentees, particularly patentees drafting or interpreting claims years after the invention itself. If the focus is on the language of my claims, not the product that I actually built or described, I can interpret that language creatively to claim, in retrospect, to own inventions that I didn't have in mind when I wrote the patent claims. ${ }^{203}$

Based on these concerns, they advocate a return to central claiming $^{204}$ and its reliance on the specification for its description of the invention. ${ }^{205}$ They argue that such a move "will help refocus patent analysis on inventions and not linguistic games." "They temper their policy proscriptions by acknowledging that "dethroning the centrality of the [peripheral] patent claim would require some significant changes to the way the current patent system operates., ${ }^{207}$

I strongly agree with their emphasis on the invention, and yet I do not think that it necessarily requires any significant statutory reform. In fact, as argued above, the proper interpretation of our current patent system is a system in which the invention is the central concept even if we still use peripheral claims as administrative tools. In this view claims do not directly define the exclusive boundaries of the patent. Instead, claims represent the invention, the thing conceived by the inventor and disclosed in the specification. And because they represent the invention, the claims can be used to fulfill patent law's statutory command to grant exclusive rights in the "patented invention." By representing a thing, despite the fact that the thing is abstract, claims are given meaning and stability. ${ }^{208}$ By linking

${ }^{202}$ Burk \& Lemley, supra note 177 , at 1747.

${ }^{209}$ Id. at 1762.

204 Id. at 1799.

${ }^{205}$ Id. at 1747 .

${ }^{206}$ Id. at 1796.

${ }^{207}$ Id. at 1783.

${ }^{208}$ See Netword, LLC v. Centraal Corp., 242 F.3d 1347, 1352 (Fed. Cir. 2001)

("The claims are directed to the invention that is described in the specification; they do not have meaning removed from the context from which they arose."). 
claim interpretation so closely to the invention described in the specification, many of the central claiming advantages advocated by Burk and Lemley should appear in our already existing peripheral claiming system. The key is to openly recognize the invention as a substantive concept. ${ }^{209}$

In the substantive view, the claims are proxies for the invention and the specification ensures the fidelity of that relationship. This aids claim interpretation. Once a patent application complies with that requirement, then indeed patent law can reference the claims rather than referencing the invention. For example, after complying with $§ 112$ I 1 , though novelty asks whether "the invention was known or used before," ${ }^{210}$ or, after passage of the Leahy-Smith America Invents Act, whether "the claimed invention was . . in public use . . . before,"211 patent law can replace the invention or the claimed invention with the claimed subject matter. Similarly and perhaps most importantly for public notice reasons, the patent system can also confidently replace the "patented invention" in the infringement context with "the claimed subject matter." In short, the disclosure requirements of $\S 112$ I 1 ensure that the claims are accurate proxies for the invention while the indefiniteness requirement housed in $\S 112$ II 2 ensures that they are precise proxies.

Claims can and do play a central role in this system. But they are important not because the claims are the invention but rather because the claims are proxies for the invention. In other words, the invention is the central focus and the claims are administrative tools that help administer the patent statute. ${ }^{212}$ And for that administrative proxy relationship to work, patent law must keep some conceptual distance between the claims and the invention. The law uses such proxies in many places. In agency, the purpose of the principal agent relationship is to allow the principal to delegate decision making to an agent. ${ }^{213}$ The agent acts as a proxy for the principal. Similarly, in contracts, the central issue is the agreement between the parties. Often the parties memorialize that agreement in writing, and that writ-

\footnotetext{
${ }^{209}$ See Chiang, supra note 23, at 9 ("Assuming that the claims and the specification describe the same thing, just in different ways, makes claim interpretation easier.").

${ }^{210} 35$ U.S.C. $\$ 102$ (a) (2006).

21 See Pub. L. No. 112-29; 125 Stat. 284 (2011).

212 See Lutz, supra note 18, at 470.

213 See, e.g., MARK LEE LEVINE, BUSINESS AND THE LAW 230 (1976) (noting the need for the agent to be loyal and obedient to the interests of the principal).
} 
ten document then serves as an objective proxy for the more abstract agreement. ${ }^{214}$

Both agency law and contract law benefit from using a proxy. Rather than bothering the principal for every decision or rather than needing to plumb the perhaps subjective recollections of a contractual agreement, we can instead rely on the agent or the written document respectively. As part of such a system, both agency law and contract law keep the principal conceptually separate from its proxy even though in day-to-day operation we might conflate the two. For example, even though in lazier moments we might say that the written document is the agreement, and we might even note that in most circumstances the written document itself can answer most major questions about the agreement, the agreement and the written document are conceptually kept apart. The reason for this separation is simple. For a proxy system to work, the law must maintain some skepticism (rebuttable though it may be) that monitors that the proxy properly serves as a proxy.

Exactly along these lines, the substantive invention uses claims as proxies for the invention. ${ }^{215}$ When the claims precisely and accurately reflect the invention, the claims can then be efficiently referenced rather than requiring a direct reference to the invention. Yet just as with contract and agency, patent law needs to keep the invention conceptually separate from the claims. And the patent statute needs to enforce that proxy relationship. Like the duty of loyalty in agency or like the suspicion with which judges approach purported integration clauses in contract law, patent law imposes a duty of fidelity on the claims so that they function as proxies for the invention. As noted in Phillips, "The claims, of course, do not stand alone. Rather, they are part of 'a fully integrated written instrument.","216

In the patent statute, $\S \S 112$ II $1-2$ perform this critical function of certifying the proxy relationship. They require the patentees to prove that they have indeed invented the subject matter that they claim to have invented. In other words, the description must be detailed enough so that the description itself can corroborate that the

${ }^{214}$ See, e.g., id. at 189 ("[T]he written memorandum . . . will evidence a contract.").

${ }^{215}$ See James W. Dabney, KSR: It Was Not a Ghost, 24 SANTA Clara Computer \& HiGH TECH. L.J. 131, 144 n.69 (2007).

${ }^{216}$ Phillips v. AWH Corp., 415 F.3d 1303, 1315 (Fed. Cir. 2005) (en banc) (quoting Markman v. Westview Instruments, Inc., 52 F.3d 967, 978 (Fed. Cir. 1995) (en banc)); see also Markman v. Westview Instruments, Inc., 517 U.S. 370,389 (1996) ("[A claim] term can be defined only in a way that comports with the instrument as a whole."). 
inventor indeed invented (meaning conceived and reduced to practice) the claimed subject matter. And the claims are written to circumscribe varying sets of these disclosed embodiments. "The patent system is based on the proposition that claims cover only the invented subject matter." ${ }^{217}$ As stated by the Supreme Court, "“[I]t seems to us that nothing can be more just and fair, both to the patentee and the public, than that the former should understand, and correctly describe, just what he has invented, and for what he claims a patent." ${ }^{218}$

This purpose then becomes very important in later interpreting the claim language. "[I]t is fundamental that claims are to be construed in the light of the specifications and both are to be read with a view to ascertaining the invention." ${ }^{219}$ That purpose gives contextual meaning to the interpretive process. Knowing why claims were written is essential in properly interpreting them later. That understanding gives previous statements about claim interpretation greater import. For example, Phillips held that "[i]mportantly, the person of ordinary skill in the art is deemed to read the claim term not only in the context of the particular claim in which the disputed term appears, but in the context of the entire patent, including the specification." ${ }^{220}$ This should not be read as simply asking a person of skill to read the specification and then define some disputed claim terms based on her understanding of the term. Rather, the person of skill needs to read the specification and the claim and then interpret the claim language to determine what set of embodiments disclosed in the specification the applicant intended to circumscribe with that particular claim. This notion was best described in Renishaw and was later cited in Phillips. "[T] he interpretation to be given a term can only be determined and confirmed with a full understanding of what the inventors actually invented and intended to envelop with the claim.,"221

\section{SUBSTANTIVE INVENTION AS COLlateral DAMAGE}

In light of this large misstep that has befallen modern patent law, the question immediately arises: How could patent law have taken such a fundamental wrong turn? This Part provides some histori-

\footnotetext{
${ }^{217}$ Phillips, 415 F.3d at 1321.

${ }_{218}$ Id. (quoting Merrill v. Yeomans, 94 U.S. 568, 573-74 (1876)).

219 United States v. Adams, 383 U.S. 39, 49 (1966); see also Phillips, 415 F.3d at 1316.

${ }^{220}$ Phillips, 415 F.3d at 1313 (quoting Renishaw PLC v. Marposs Societa' per Arizona, 158 F.3d 1243, 1250 (Fed. Cir. 1998)).

${ }^{221}$ Id. at 1316.
} 
cal context and argues that it is not just that we have forgotten about the invention; rather, it was actively purged from our thinking because of mistaken identity.

Up until the 1950s the term invention was being used in very confusing ways. The invention "came to be used to refer to the thing invented and also to some vague quality necessary to patentability.",222 Patent law was structured so that an "invention (in the concrete sense) [might be found] unpatentable because it is not an invention (in the abstract sense). ${ }^{223}$ These usages were confusing and were leading to "muddy thought." ${ }^{224}$ At the time the 1952 Patent Act was drafted, one usage of the term "invention" had indeed become very problematic. This was the court-created "requirement of "invention.","225

The patent lawyers of the era "meekly accepted it as an article of faith-with plenty of experience to back it up-that 'invention,' [referring to the requirement of invention] indeed could not be defined." The "requirement of invention" was "that "beautiful uncertainty in the law' from which the patent bar made its livingpracticing what was essentially a mystery. ${ }^{227}$ Judge Learned Hand commented that "[the requirement of invention] is as fugitive, impalpable, wayward, and vague a phantom as exists in the whole paraphernalia of legal concepts., ${ }^{228}$ The situation soon worsened to the point that the confusion became unacceptable. Senate reports identified "the greatest technical weakness of the patent system ... [as] the lack of a definitive yardstick as to what is invention." ${ }^{229}$ Congress responded and recruited then-patent attorney Giles Rich, among others, to help draft the 1952 Patent Act. ${ }^{230}$

The drafters of the 1952 Act, recognizing the troubles with the "requirement of invention," did not incorporate that requirement into the codification. The drafters ultimately decided to "get away 2:9.

${ }^{222}$ Giles S. Rich, Principles of Patentability, in NONOBVOUSNESS, supra note 19, at 2:1,

${ }^{223}$ Giles S. Rich, The Vague Concept of "Invention" as Replaced by $\S 103$ of the $1952 \mathrm{~Pa}$ tent Act, 14 FED. CIR. B.J. 147, 162 (2004).

224 Id.

${ }^{225}$ Giles S. Rich, Why and How Section 103 Came to Be, in Nonobviousness, supra note 19 , at 1:201, 1:201.

${ }^{226}$ Id. at $1: 208$.

${ }^{227}$ Id. at $1: 205$.

${ }^{228}$ Harries v. Air King Prods. Co., Inc., 183 F.2d 158, 162 (2d Cir. 1950).

${ }^{229}$ Rich, supra note 225, at 1:207.

${ }^{290}$ Giles S. Rich, Congressional Intent-Or, Who Wrote the Patent Act of 1952, in NONOBVIOUSNESS, supra note 19 , at 1:1, 1:1. 
from this troublesome term altogether' .... 'Let's not use [the term invention] at all and say what we really mean, and speak in terms of a requirement for patentability." ${ }^{231}$ From that, the now familiar requirement of obviousness was codified in 35 U.S.C. $\$ 103$. It avoided all reference to the requirement of invention. ${ }^{232}$ The drafters' entire focus was the one troublesome usage and it was excised from the statute. I have no quibble with that change. ${ }^{23}$

Unfortunately, despite its replacement in the new statute, patent law only slowly started to reflect the change. ${ }^{234}$ Courts continued to refer to the requirement of invention rather than the newly minted statutory requirement of obviousness. A struggle ensued between those that were following the new statute and those that stubbornly held onto the older terminology, most notably members of the Supreme Court. ${ }^{235}$

The drafters of the new act undertook a rhetorical campaign to reeducate patent lawyers and judges and to purge the requirement of invention from the patent lexicon. Judge Giles Rich, one of the founders of modern patent law, metaphorically "open[ed] [a discussion of modern patent law] with prayers and a burnt offering [of] all of the textbooks on patent law which talk about the requirement of 'invention." ${ }^{236}$ In large part the purge was successful; ${ }^{237}$ patent law-

231 Rich, supra note 225, at 1:209.

232 Actually, it does use the invention, but as this Article makes clear, it is used in its concrete sense, the sense that was not problematic.

${ }^{233}$ The change was certainly a statutory and rhetorical change. What remains controversial is whether the change was also a substantive change or whether it kept the level of patentability the same but only changed the way in which we discuss that level.

${ }^{234}$ Giles S. Rich, Laying the Ghost of the "Invention Requirement," in NONOBVOUSNESS, supra 19, at 1:501, 1:511 ("[F] or the first few years [after 1952] courts were not heeding the statute.").

${ }^{235}$ Id. at 1:515-16. See also Herbert Mintz \& Charles O'Rourke, After Black Rock: New Tests of Patentability-The Old Tests of Invention, 39 GEO. WASH. L. REV. 123, 123 (1970) ("In Anderson's-Black Rock, Inc. v. Pavement Salvage Co. the Supreme Court revived the illusory 'invention' standard as a requisite of patent validity. In light of its apparent rejection by Congress and subsequent abandonment by the Court [in Graham v. John Deere], the reappearance of this standard in Black Rock raises, questions of vital concern to proponents of a functional patent system.").

${ }^{236}$ Rich, supra note 225, at 1:201. Indeed, at the time the 1952 Patent Act was being drafted, Giles Rich had a good reason to worry about how invention was being misused in patent law. See infra note 27-32 and accompanying text (discussing the problems with the requirement of invention and how the usage of the invention in any form was purged as a result).

${ }^{237}$ The controversy surrounding obviousness that ultimately lead to the $K S R$, International, Co. $v$. Teleflex case can be seen in part as a remnant of that battle between the new statutory standard of obviousness and the older requirement of invention, 
yers now rightfully talk about obviousness rather than the requirement of invention.

But as with any zealous purge, things often go astray; there is collateral damage. In this case, the concrete use of "the invention," referring to the subject matter conceived by the inventor, was purged along with the problematic "requirement of invention." In modern patent law, the prohibition on uttering "the invention" has been too successful; Judge Rich's prayers have come true. ${ }^{238}$ No modern patent textbook explores any substantive definition of the invention. The patent bar has been taught to avoid using the term invention in any substantive form; it is a relic from an older, subjective, and likely dysfunctional patent system.

For example, during the relatively recent oral arguments in $K S R$ International, Co. v. Teleflex, Inc. ${ }^{239}$ Justice Stevens was exploring the details of the solution offered by the patentee. This is the exact place where it is helpful and correct to ask about the invention, the thing conceived by the inventor. Justice Stevens, however, asked whether " $[t]$ he invention, to use an old-fashioned term, is the decision of

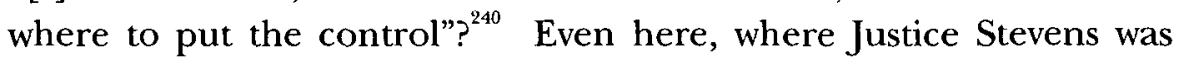
asking about the details of the concrete solution described in the patent, he felt some discomfort in using the term "invention" despite the fact that it appears 250 times in the statute. We have been taught that invention is not the right way for the initiated to discuss patent law. The concrete usage of the invention, referring to the thing actually invented, has fallen victim to modern patent law's cult of the claim. And as relayed in this Article, patent law is currently suffering from its inability to use this important term properly. The time has come to begin using the term invention in the substantive way in which the statute demands.

\section{FURTHER IMPLICATIONS OF SUBSTANTIVE INVENTION}

In addition to the benefits already described, there are other areas in which the substantive vision of the invention will have an impact on patent law and theory. This Part sketches three of these areas.

especially as a fight between how the two tests compare to each other. See Dabney, supra note 215, at 146.

${ }_{238}$ See supra note 232 and accompanying text.

239550 U.S. 398 (2007).

${ }^{240}$ Transcript of Oral Argument at 55, KSR Int'l, Co., v. Teleflex, Inc., 550 U.S. 398 (No. 041350); see also Dabney, supra note 215, at 147. 


\section{A. Inventing the Future Before It Arrives}

Closely related to both the disclosure requirements and claim interpretation, there is presently conceptual and doctrinal confusion surrounding claim scope and its relation to after-arising technology. ${ }^{24}$ Imagine inventing the chair and disclosing how to make a chair out of wood. You are granted a patent over this. Imagine that soon thereafter carbon fiber is invented and someone starts manufacturing chairs not from wood but instead built from carbon fiber. Should that carbon fiber chair infringe the earlier patent? Equivalently, if the claim can literally be interpreted to include such a chair, how could such a claim be valid under $\S 112$, and, more generally, how could a patentee enable a person of skill to make and use carbon fiber before it has been invented (whether for chair building or not)?

These are the types of questions that surround the issue of patents and after-arising technology. Scholars are divided. ${ }^{242}$ Some have solved this "temporal paradox" by arguing that enablement requires the claim to be enabled as of its filing date while infringement is measured at the time of infringement. ${ }^{243}$ Thus, a broad claim will be valid if it enables the claimed subject matter as "it was understood at the filing date," and yet it can still "cover" all variants covered by claim (even later developed ones) interpreted as of the date of infringement. ${ }^{244}$ Other scholars disagree, arguing that claim language for validity and infringement should be interpreted consistently and therefore the courts should use one single temporal frame of reference. ${ }^{245}$ As a result, the idea that claims could expand later would have to be rejected. ${ }^{246}$

Similarly, the issue is not settled in the courts. They have held that it is an error to require a patentee to "enable nonexistent tech-

${ }^{241}$ See Cotropia, supra note 12, at 540 (“An 'after-arising' technology is a technology that 'come[s] into existence after the filing date of a[] [patent] application."' (quoting In re Hogan, 559 F.2d 595, 605 (C.C.P.A 1977))).

${ }_{242}$ See Burk \& Lemley, supra note 178, at 1764; Kevin Emerson Collins, Enabling After-Arising Technology, 34 J. CORP L. 1083 (2009); Cotropia, supra note 12, at 540; Feldman, supra note 161, at 3 ("Modern case law reflects confusion over whether the footprint of an invention includes things unknown at the time of the invention."); Lefstin, supra note 10, at 1156.

${ }^{243}$ See MERGES, supra note 90, at 299-300 (describing this as the "temporal paradox").

${ }^{244}$ Id.

${ }^{245}$ See Mark A. Lemley, The Changing Meaning of Patent Claim Terms, 104 MicH. L. REv. 101, 120 (2005).

${ }^{246}$ Id. 
nology" ${ }^{247}$ as that would "impose an impossible burden on inventors and thus on the patent system." ${ }^{248}$ But it is less clear whether such claims can later be interpreted more broadly for infringement purposes. In Chiron, the Federal Circuit did not have to reach the issue as the invalidity of the claims was affirmed, but the court acknowledged "a dilemma" whether that claim should be interpreted "according to meaning [of the disclosure]" or whether to "construe the term [according to the later meaning that is] broader than the disclosure. ${ }^{249}$ At least one judge made it clear that he would not later interpret the claim more broadly. The "proper approach ... is [to] constru[e] claims ... as they would have been understood by one of skill in the art at the time of the invention, and not [to]construe them to reach the as-yet-undeveloped technology that the applicant did not enable. ${ }^{250}$

These challenging issues can be nicely solved by turning to the substantive vision of the invention. Many might wrongly assume that the substantive notion of the invention necessarily leads to narrow claim scope. But in fact, the substantive vision can support broad claims. Broad claims are allowed where the patentee discloses and claims a broad conception. This can be done rather easily where a patentee understands the principle behind the invention. Knowing how and why one solution to some problem works often allows the inventor to conceive and disclose other embodiments that will similarly work. Not only does this allow for a broad disclosure of presently existing embodiments, but it also can in many cases allow for disclosure of embodiments that use components that do not yet exist. ${ }^{251}$ Disclosure of the principle of the invention has been part of patent law for a long time.

${ }^{247}$ Chiron Corp. v. Genentech, Inc., 363 F.3d 1247, 1255 (Fed. Cir. 2004). Note that the invalidity of the non-original claim in Chiron was supported by the failure to comply with the written description requirement.

${ }_{248}^{24}$ In re Hogan, 559 F.2d 595, 606 (C.C.P.A. 1977); see also Chiron, 363 F.3d at 1254 (" $[\mathrm{A}]$ patent document cannot enable technology that arises after the date of application. The law does not expect an applicant to disclose knowledge invented or developed after the filing date.").

${ }^{249}$ Chiron, 363 F.3d at 1258.

${ }^{250}$ Id. at 1263 (Bryson, J., concurring).

${ }^{251}$ See Lefstin, supra note 10, at 1122 n.259; Lutz, supra note 18, at 465; Michael J. Meurer \& Craig Allen Nard, Invention, Refinement and Patent Claim Scope: A New Perspective on the Doctrine of Equivalents, 93 GEO. L.J. 1947, 1961-66 (2005).

${ }_{252}$ See Cont'l Paper Bag Co. v. E. Paper Bag Co., 210 U.S. 405, 418-19 (1908) (focusing on the principle of the invention, not a specific embodiment); Winans $v$. Denmead, 56 U.S. (15 How.) 330, 343 (1853) (focusing on the "substance of the invention"); see also Chiang, supra note 23, at 3; Lutz, supra note 18, at 460. 
For example, suppose I disclose a chair made from wood and I also disclose the basic engineering principles that make the chair work and I make it clear that it need not be made from wood; then this lays the groundwork for literal claims that could be applied to chairs made from after-arising materials. Suppose I explain that the four legs need to be made from a material such that each leg can support one quarter of the weight of a human plus some margin of safety. At some later date, after carbon fiber and polymer resin composites have been invented, persons of skill in furniture making will read my specification and they will be able to build a carbon fiber chair not because they could make and use it after reading my specification but because they would do so-the specification would tell them to use materials other than wood as long as those materials met the mechanical properties outlined by the specification. Such a broad conception demonstrates what I call a trans-technological invention. It can cover embodiments that were not explicitly foreseen but that were nonetheless explicitly taught by the specification.

By understanding their invention at a trans-technological level, a patentee can describe these solutions in rather abstract but still specified terms. As it relates to after-arising components, this broad understanding of the underlying principles allow that patentee to communicate to future persons of skill in the art. If and when such disclosures are made, patent claims could well cover embodiments that use components that did not exist at the time the patent was filed.

In addition to addressing after-arising technology, the substantive invention also addresses confusion over the correct time frame for interpreting claim language. Claims are interpreted as of the filing date but they are construed as of the date of infringement. This allows validity to be judged at filing, but it allows the set of embodiment to grow if indeed the patentee managed to disclose and claim such a trans-technological invention. Interestingly, a corollary to this discussion is that substantive vision would not permit the "classic" blocking patent scenario. Claims could only cover embodiments that the specification teaches. This necessarily means that claimed embodiments are obvious and not patentable by later patenteess. ${ }^{2.33}$ This prevents the classic improvement-blocking patent. Blocking patents

253 See Charles W. Adams, Allocating Patent Rights Between Earlier and Later Inventions, 54 ST. Louis U. L.J. 55 (2010) (making similar arguments based on the full-scope enablement cases coupled to nonobviousness). 
could still occur but in limited circumstances. For example, they could still emerge for component-style-blocking patents. ${ }^{25}$

\section{B. Finding Invention}

Having just sketched how the substantive vision of the invention can provide patent claims that encompass after-arising technology, it should be emphasized that not all inventions can be claimed as broadly. Not all inventions are created the same. Some classes of invention are necessarily much narrower. Further exploration of the invention reveals a spectrum between high and low inventorship akin to the distinction between high and low authorship in copyright.

From a distance, much of copyrightable subject matter looks the same-from a distance all "writings" look similar. From a distance, it is hard to tell whether a book on a shelf is a novel or a laborious listing of scientific facts. On closer inspection, however, the average person, and indeed copyright, treat a novel quite differently from a phone directory. Copyright affords one, the novel, a relatively broad copyright, while it affords the other, the directory, a very narrow one. As summarized by Jane Ginsburg,

We have now, as we have long had, two kinds of copyrights: in high authorship works, such as novels and narrative histories, copyright protects the authorial presence within the work; in low authorship works, such as telephone directories and compilations of stock quotations, copyright protects the labor and resources invested in the work's creation.

Importantly, the monikers "high" and "low" authorship and their concomitant scope of copyright are not attempts to denigrate the social value of fact intensive works. Undoubtedly, on any stormy night a navigator would surely trade the best novel in the world for an accurate chart. Nonetheless the scope of low authorship works is much smaller than high authorship works.

Akin to these low authorship works in copyright, some inventions are just not as broad as others. Much of biotechnology still finds incredibly important solutions by trial and error (albeit via clever and sophisticated trial and error screening techniques). ${ }^{256}$ This will

${ }^{254}$ See Kevin E. Collins, Getting into the Spirit of Innovative Things: Looking to Substitute and Complimentary Properties to Shape Patent Protection for Improvements, 26 BERKELEY TECH. L.J. 1217 (2011) (highlighting these "easy" cases of component blocking patents (internal quotation marks omitted)).

${ }^{255}$ Jane Ginsburg, Creation and Commercial Value: Copyright Protection of Works of Information, 90 COLUM. L. REV. 1865, 1870 (1990).

${ }^{256}$ See Bruce Alberts et al., MOlecular Biology of the Cell 187-88 (3d ed. 1994). 
likely impact many very important areas of biotechnology including gene patents, cell lines, and monoclonal antibody patents. ${ }^{257}$

These are areas where patent claims today are quite broad compared to the actual invention. In most cases, one actual embodiment is disclosed often by way of biological deposit, but the claims cover far more than the one deposited embodiment. In the cult's view of the patent system, this does not pose any real problem, but it creates real problems in the eyes of the substantive invention. The real question in these cases is whether the patentee has actually invented any more than the one deposited embodiment. Generally there is nothing in the specification that evidences conception of anything beyond the one deposited embodiment. That disparity between the one solution disclosed and the solutions claimed is why these inventions should be viewed as identical to the over-reaching patentees in The Incandescent Lamp Case. ${ }^{258}$ Where a solution to a technical problem is found through trial and error (even sophisticated, elegant trial and error like in the case of antibodies) without further discovering how to extrapolate to other solutions from the one found solution, claims cannot exceed that one particular solution. ${ }^{259}$ Finding invention without more is the quintessential act of low inventorship and the resulting patent cannot have broad claims.

\section{Patent Theory: Focus on Inventions, Not Legally Created Incentives}

In addition to the many doctrinal and practical changes, the substantive vision of the invention leads to a serious rethinking of fundamental patent theory. There are many theories of the patent system. They differ in detail yet they all share one common assumption. Though a free market works well with tangible goods, it is thought that it is ill-suited for inventions as the copying inherent in a competitive market makes it impossible to recover the often large fixed costs of creating the inventions. The patent system therefore is seen as an exception to a competitive market. In particular, patents are designed to artificially interfere with the market to create incentives.

Patent claims are seen as this incentive and the U.S. Patent and Trademark Office and the courts are therefore seen as balancing the incentives created by a patent's exclusive rights against its costs. The trouble is that no one knows how to quantify these costs or benefits

${ }^{257}$ See Liivak, supra note 71, at 3.

${ }^{258}$ Consol. Elec. Light Co. v. McKeesport Light Co. (The Incandescent Lamp Case), 159 U.S. 465 (1895).

${ }^{259}$ See id. at 472. 
and despite two hundred years of heated debate, we still cannot conclude if, on balance, our patent system is worth it. Instead, support for, or criticism of, the patent system has been based ultimately on belief. Patent debates have pitted "[c]onviction ... against conviction, argument against argument, assumption against assumption.".600 Judge Learned Hand testified before the Senate that

[t] here are two schools and the one school beats the air and says without the patent system the whole of American industry would never have been developed. [The patent system] is the stimulus which has brought us to the top, and the other says it is nothing but a beastly method .... No one really knows. Each side is beating the air. They approach it with enormous passion but without enlightenment.

Over fifty years ago, the Senate, worried about this issue, asked economist Fritz Machlup to resolve this empirical cost-benefit question. After an extensive ninety page report weighing the evidence, he gave the following dispiriting conclusion:

If we did not have a patent system, it would be irresponsible, on the basis of our present knowledge of its economic consequences, to recommend instituting [it]. But since we have had [one] for a long time, it would be irresponsible, on the basis of our present knowledge, to recommend abolishing it.

Perhaps we have made the problem too complicated. As suggested by the doctrinal focus on the invention, perhaps patent law and patent theory should not be about legally created incentives at all but should be instead about exclusivity over the invention alone.

Patent law should be viewed as part of the legal infrastructure for an institution that enables inventors to create and sell inventions. ${ }^{263}$ We need not ask how much legally created incentive some inventor needs. Instead, we presume that useful inventions have their own inherent economic incentives-if the invention is useful, people will want to buy it. The purpose of the patent system is not to provide incentives, but rather, to prevent the third party acts that would prevent

${ }^{260}$ Fritz Machlup \& Edith Penrose, The Patent Controversy in the Nineteenth Century, 10 J. ECON. HisT. 1, 28 (1950).

${ }_{261}$ The American Patent System: Hearing Before the Subcomm. on Patents, Trademarks, and Copyrights of the S. Comm. on the Judiciary, 84th Cong. 116 (1956) (statement of Judge Learned Hand).

${ }^{262}$ Fritz Machlup, An Economic Review of the Patent System, Subcomm. ON Patents, Trademarks, and Copyrights of THE Senate Comm. ON THE Judiciary 80 (1958).

${ }^{263}$ This also includes business models that aim to create inventions and sell products or services that embody the inventions. 
inventors from benefiting from the already existing economic incentives. Congress has already decided how much protection is needed to allow for those economic incentives to flow to the inventor. By granting the exclusive rights over the patentable invention, Congress has created a property system. Property, as stated by Bentham, does not "reward," rather, it "preserves" "recompense" by "arresting the hand that may seek to ravish ... from you." Compared to the incentive-based theories and their impossible task of balancing incentives against costs, this simplified invention theory paints a very important yet narrower and more manageable role for the patent system.

\section{CONCLUSION}

Modern patent law does not think much about the invention. The term surely gets used, but it is currently just a shorthand reference for the claimed subject matter. The patent system that has emerged from that trivial vision of the invention is failing to provide its promise of precision and accuracy. The problem is the trivial vision of the invention.

By seeing the invention as a substantive concept, the patent system can improve completeness, accuracy, and precision. The invention is the set of embodiments conceived, disclosed, and claimed by the inventor. With that substantive vision, we once again put the invention at the center of patent law and the claims are viewed as important yet administrative tools for securing exclusive rights in the invention. That vision leads to a disclosure requirement that aims to evidence what was in fact invented. It gives claims meaning and gives judges context to interpret claims. Lastly, it necessarily limits patent claims to the substantive invention created by the inventor.

${ }^{264}$ JEREMY BENTHAM, THE THEORY OF LegisLATION 110 (C.K. Ogden ed., Harcourt, Brace \& Co. 1931) (1802). 